\title{
Pharmacotherapy in Secondary Progressive Multiple Sclerosis: An Overview
}

\author{
Floriana De Angelis ${ }^{1}$. Domenico Plantone ${ }^{1}$. Jeremy Chataway ${ }^{1}$
}

Published online: 3 July 2018

๑) Springer International Publishing AG, part of Springer Nature 2018

\begin{abstract}
Multiple sclerosis is an immune-mediated inflammatory disease of the central nervous system characterised by demyelination, neuroaxonal loss and a heterogeneous clinical course. Multiple sclerosis presents with different phenotypes, most commonly a relapsing-remitting course and, less frequently, a progressive accumulation of disability from disease onset (primary progressive multiple sclerosis). The majority of people with relapsing-remitting multiple sclerosis, after a variable time, switch to a stage characterised by gradual neurological worsening known as secondary progressive multiple sclerosis. We have a limited understanding of the mechanisms underlying multiple sclerosis, and it is believed that multiple genetic, environmental and endogenous factors are elements driving inflammation and ultimately neurodegeneration. Axonal loss and grey matter damage have been regarded as amongst the leading causes of irreversible neurological disability in the progressive stages. There are over a dozen disease-modifying therapies currently licenced for relapsing-remitting multiple sclerosis, but none of these has provided evidence of effectiveness in secondary progressive multiple sclerosis. Recently, there has been some early modest success with siponimod in secondary progressive multiple sclerosis and ocrelizumab in primary progressive multiple sclerosis. Finding treatments to delay or prevent the courses of secondary progressive multiple sclerosis is an unmet and essential goal of the research in multiple sclerosis. In this review, we discuss new findings regarding drugs with immunomodulatory, neuroprotective or regenerative properties and possible treatment strategies for secondary progressive multiple sclerosis. We examine the field broadly to include trials where participants have progressive or relapsing phenotypes. We summarise the most relevant results from newer investigations from phase II and III randomised controlled trials over the past decade, with particular attention to the last 5 years.
\end{abstract}

\section{Key Points}

Many anti-inflammatory, reparative or neuroprotective agents are currently in the pipeline for secondary and primary progressive multiple sclerosis

New trial designs may expedite the discovery of therapeutic compounds for progressive multiple sclerosis

The use of repurposed drugs and combination therapies are promising strategies to prevent or mitigate secondary progressive multiple sclerosis

Floriana De Angelis

f.deangelis@ucl.ac.uk

1 Queen Square Multiple Sclerosis Centre, Department of Neuroinflammation, UCL Institute of Neurology, Faculty of Brain Sciences, UCL, London, UK

\section{Introduction}

Multiple sclerosis (MS) is an immune-mediated inflammatory disease of the central nervous system (CNS) characterised by demyelination, neuroaxonal loss and a heterogeneous clinical course. The most common presenting form of MS is relapsing-remitting (RRMS), affecting about $85 \%$ of the newly diagnosed patients. After $10-15$ years, more than $50 \%$ of patients with RRMS convert to the secondary progressive stage of the disease (SPMS), characterised by a gradual neurological decline and none or rare relapses. In about $15 \%$ of the cases, MS has a progressive course from the beginning (primary progressive MS [PPMS]). The clinically isolated syndrome (CIS) is a condition characterised by one neurological clinic event with associated neuroimaging features of demyelination that does not fulfil the MS diagnostic criteria $[1,2]$. The risk of conversion of CIS to clinically definite MS is about $45 \%$ within 2 years [3]. Finally, with the spreading use of magnetic resonance imaging (MRI) as a diagnostic 
tool, frequent incidental findings of diffuse white matter demyelination with a distribution similar to MS have been reported. Around two-thirds of these cases, called 'radiologically isolated syndromes', show radiological progression and one-third develop neurological symptoms during a mean follow-up of 5 years [4].

We have a limited understanding of the mechanisms underlying MS, and a multidisciplinary approach is needed to clarify the complex pathophysiology of the disease. It is believed that many genetic, environmental and endogenous factors are important elements driving inflammation and ultimately neurodegeneration in MS [5]. Axonal loss and grey matter damage have been regarded as the leading causes of irreversible neurological disability in the progressive stages [6-11].

During the past two decades, findings in the pathophysiology of MS have been translated into new therapeutics that mainly target the immune system centred on RRMS. Glatiramer acetate and beta-interferons represent the first-generation disease-modifying therapies (DMTs) in MS, followed by a second generation of DMTs initiated by natalizumab and fingolimod. Further agents such as teriflunomide, alemtuzumab, dimethyl fumarate, ocrelizumab and cladribine have been approved by the principal regulatory agenciesthe US Food and Drug Administration and the European Medicines Agency (EMA)—for RRMS (Fig. 1). Despite their effectiveness in preventing new relapses or MRI lesions and in mitigating the disability progression in the short term, less is known about their efficacy on disability in the long term. Furthermore, there is less evidence of a therapeutic effect of DMTs in progressive MS, and none of these can clearly stop the transition from RRMS to SPMS.

The purpose of this review is to discuss new findings regarding immunomodulatory, neuroprotective and remyelinating approaches and therefore potential future treatment strategies for SPMS drawing broadly from the progressive and relapsing fields. We examine recent data over the last $5-10$ years.

\section{Pathogenesis of Multiple Sclerosis: From Relapsing-Remitting to Secondary Progressive Phenotype}

Many factors have been investigated in the pathophysiology of MS, although no specific trigger has been identified. Whether a CNS extrinsic or intrinsic factor drives MS is still not known. Viral infections (particularly by Epstein-Barr virus), vitamin $\mathrm{D}$ insufficiency or smoking habit have been associated with a higher incidence of MS. The expressions of the HLA alleles DRB $1 * 1501$, DRB $1 * 0301$ and DRB $1 * 1303$ on cells of the innate immune system are associated with an increased risk of developing MS [odds ratio 3.1, 1.26 and 2.4, respectively]. [12] The commonly accepted hypothesis of MS pathogenesis is that multiple factors in combination (genetic, environmental and lifestyle) act in concert and trigger an immune-mediated inflammatory process. Macrophages and microglia from the innate
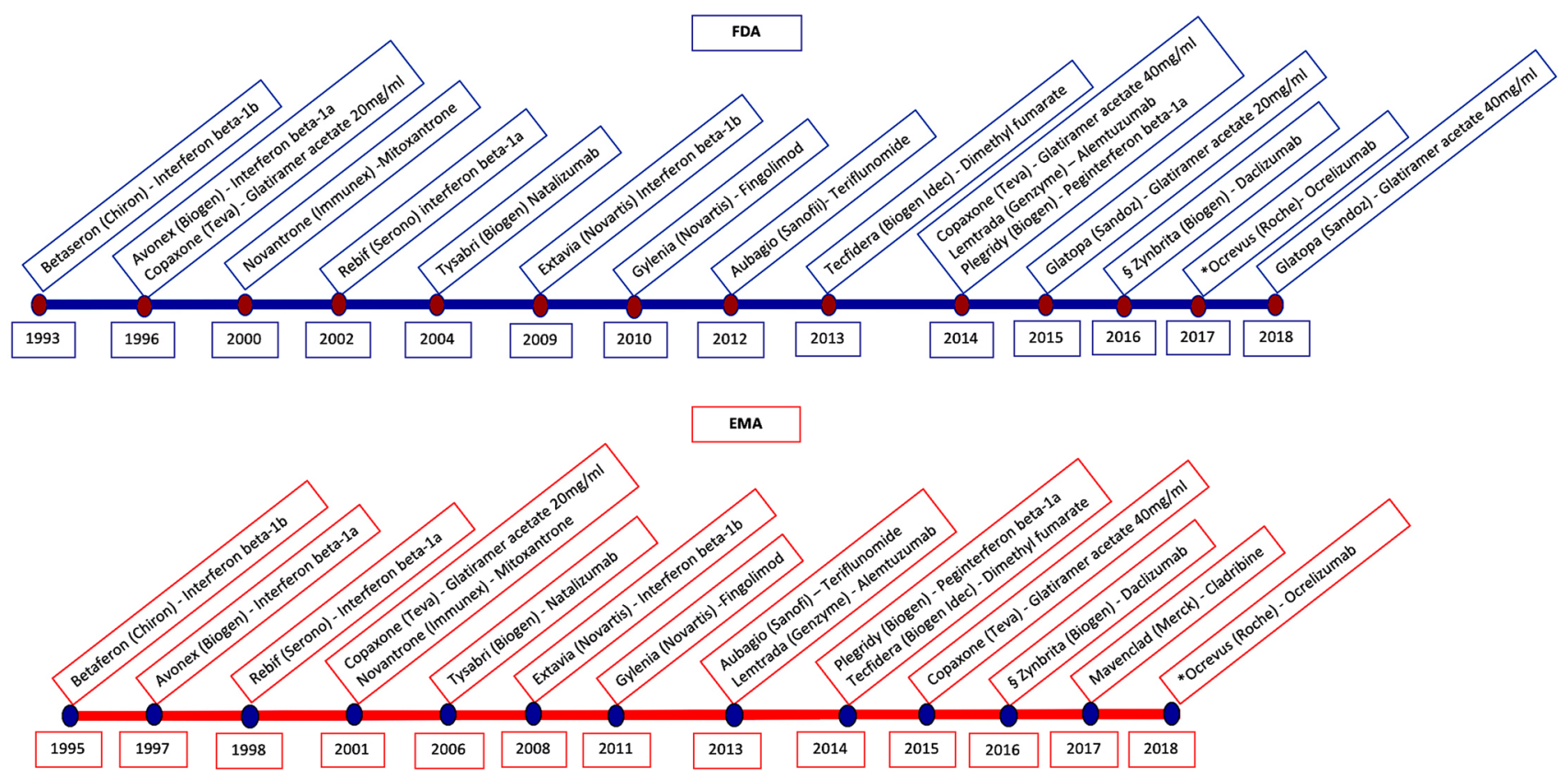

Fig. 1 Disease-modifying drugs currently approved by the US Food and Drug Administration (FDA) and European Medicines Agency (EMA) for relapsing-remitting multiple sclerosis. * Licenced also for primary progressive multiple sclerosis, ${ }^{\S}$ withdrawn 
immune system, and $\mathrm{T}$ and $\mathrm{B}$ lymphocytes from the adaptive immune system are the major contributors [13]. From the peripheral immune system, autoreactive T-helper cells are primed and stimulated to infiltrate the CNS where they activate microglia and macrophages. These induce the production of reactive oxygen species and nitric oxide, which in turn lead to neuronal mitochondrial dysfunction, energy failure and increased levels of intracellular calcium and sodium. Acidosis and glutamate-mediated excitotoxicity contribute to an increased intracellular level of calcium and ultimately apoptosis of oligodendrocytes, and degeneration of axons and neuronal death [14]. B and T cells, monocytes, natural killer cells and dendritic cells are all involved in any stage of MS, explaining why some therapeutics targeting inflammatory cells may be also effective in progressive MS [15].

Despite the differences in clinical phenotypes, neuropathology studies have found that the patterns of inflammation are very similar between relapsing and progressive MS, showing the same infiltrates, mostly CD8+ T lymphocytes, CD20+ B cells and plasma cells, although the proportions of the single immune factors may differ. In RRMS, inflammatory infiltrates are associated with blood-brain barrier (BBB) damage, and there is an abundance of new focal white matter lesions showing active demyelination. In progressive MS, instead, inflammation is compartmentalised behind an apparently normal BBB, and acute plaques are rare, while chronic plaques are abundant and show a slowly expanding rim of activated microglia and macrophages containing myelin degradation products at borders $[5,16]$. The concept that the BBB is intact in progressive MS, and therefore that mediators of DMTs cannot penetrate the CNS to exert their action, has been recently challenged by a study showing that there is a marked deposition of fibrin(ogen) - a marker of BBB disruption-in the cortex of patients with progressive MS [17].

Multiple sclerosis plaque location is spread in the CNS of all phenotypes, involving both grey and white matter. In the later stages of the disease, there is diffuse and often extensive cortical demyelination that correlates with neuroaxonal loss and motor and cognitive disability [18, 19]. Cortical demyelination extends along the subpial surface of the cortex and seems to be pathognomonic of MS, as there is no evidence of such cortical damage in other neurological disorders. The exact pathogenesis of cortical lesions is debated, but it is believed to be linked to a local accumulation of proinflammatory cells or soluble factors from the meninges. In areas of reduced cerebrospinal fluid (CSF) flow, meningeal ectopic B-cell follicle-like structures have been identified and associated with SPMS, suggesting that meningeal inflammation may play a role in neurodegeneration [20, 21]. Lisak and colleagues also demonstrated that B cells from patients with RRMS, but not from healthy controls, secrete factors in vitro toxic to neurons and oligodendrocytes independent of immunoglobulins, not complement mediated and involving apoptosis. They hypothesised that B cells entering the meninges and CSF from the peripheral immune system could secrete soluble factors different from antibodies that lead to the characteristic damage of MS in the underlying cortical grey matter [22,23]. Finally, profound diffuse pathology can be found in the normal-appearing white and grey matter, where there is evidence of perivenous inflammatory infiltrates surrounded by rims of demyelination, diffuse astrocytic gliosis, microglia activation and axonal degeneration.

From a diagnostic perspective, it may be difficult to identify the conversion from RRMS to SPMS or distinguish between PPMS and SPMS. To date, there are no clear pathologic, imaging, immunological or clinical criteria to identify the exact point of conversion from RRMS to SPMS, which is usually gradual and based on the observation of relentless increasing disability. Although PPMS and SPMS are considered as separate phenotypes, clinical, imaging and genetic data suggest that there are no pathophysiologically distinct features [2].

\section{Measures of Neuroaxonal Loss in MS Clinical Trials}

A detailed description of clinical trial outcome measures is beyond the scope of this review and exhaustive reads of this topic can be found elsewhere [24-27]. Clinical trials with 1to 3-year follow-up in progressive MS have to infer long-term irreversible disability outcomes from short-term confirmed progression events [28]. Outcome measures related to progression vary across trials. The more recent phase III clinical trials primarily focus on the time to confirmed disability progression or the proportion of patients with or without confirmed disability progression. In phase III trials, disability progression is usually assessed on clinical grounds by means of the Expanded Disability Status Scale (EDSS), the MS Functional Composite (MSFC) and its sub-components, or recently by a combination of EDSS and/or walking and/or upper limb progression [29-31]. Despite its widespread use, the EDSS is a non-linear scale mostly weighted towards motor and lower limb functions and has shown low inter- and intra-rater reproducibility [32]. The MSFC is a composite score weighted on three components testing lower limb (timed 25-foot walk [T25FW] test), upper limb (9-hole peg test [9HPT]) and cognitive function (Paced Auditory Serial Addition Test [PASAT]). The PASAT has been criticised because of its practise effects and patient frustration with the test. Like the PASAT, the Symbol Digit Modalities Test (SDMT) can measure the speed of information processing, one of the cognitive domains more often affected in MS, most reliably than the PASAT and without causing anxiety in patients. The SDMT seems to be the 
neuropsychological test most sensitive to the MS cognitive disorder and correlates well with MRI measures of atrophy and lesion burden, and it has been proposed that the SDMT should replace the PASAT in the MSFC $[33,34]$. In trials testing the visual pathways, and in general to add a sensitive measure of the vision function in MS trials, the Sloan low-contrast letter acuity has been used [35, 36].

In phase II trials, disease progression is measured by means of imaging or laboratory biomarkers that have been linked to neuroaxonal loss [37]. Quantitative MRI can measure: (1) active inflammation, by counting new or enlarged $\mathrm{T} 2$ lesions or gadolinium-enhancing lesions (GELs), and (2) neuroaxonal loss, by calculating changes in the whole brain volume (or regional grey matter and deep grey matter volumes) or spinal cord cross-sectional area, which are believed to reflect irreversible tissue damage, or atrophy $[38,39]$.

Studies of brain atrophy in patients with untreated MS and who are clinically stable have shown that brain volume loss occurs at a rate of about $0.5-1 \%$ per year compared with $0.1-0.3 \%$ in healthy controls [40] and the brain volume loss is particularly pronounced in SPMS [18, 41-43]. Neuroaxonal tissue constitutes a large proportion of brain volume and the increased rate of brain atrophy has been interpreted as evidence for neuroaxonal loss [40]. Moreover, brain atrophy significantly correlates with disability and cognitive impairment in MS [44].

Advanced MRI techniques, such as magnetic transfer ratio (MTR) or magnetic resonance spectroscopy may reflect specific myelin or neuroaxonal loss [38].

The anterior visual system, which represents the most visible part of the human brain, is a common site of damage in MS. Visual evoked potentials (VEPs) have been used for a long period to objectively quantify the axonal integrity of the visual pathways. The VEP latency has been used to confirm the efficacy of remyelination or neuroprotective drugs. More recently, optical coherence tomography has emerged in MS studies as a non-invasive tool that allows investigation of the neuronal retina [45]. Optical coherence tomography can quantify the thickness of the retinal nerve fibre layer (RNFL) made of unmyelinated axons originated from the retinal ganglion cell bodies. Ganglion cell layer and RNFL thicknesses are plausible biomarkers of neuronal and axonal loss, respectively [46]. In MS, some studies have reported significant associations between RNFL thickness and EDSS or MSFC, as well as with cognitive measures and brain atrophy [47-51]. A multicentre cohort study showed that decreased peripapillary RNFL thickness was associated with an increased risk of disability worsening during follow-up in patients with MS [52].

Laboratory biomarkers may be useful to quantify the extent of neuroaxonal loss, with blood and CSF biomarkers such as osteopontin and neurofilament light-chain levels starting to be measured in clinical trials $[53,54]$.

\section{Agents Under Investigation: From Relapsing-Remitting to Progressive MS}

To modify the natural history of SPMS, preventing or delaying the accumulation of disability should be the goal of the treatment. $\mathrm{T}$ and $\mathrm{B}$ cells migrate from the peripheral blood into the CNS inducing local inflammation and producing immunoglobulins, which can be found in the CSF. The inflammatory activity of RRMS can be targeted in different ways, mostly blocking the trafficking of lymphocytes from the periphery to the CNS or by depleting the number of lymphocytes to reduce the amount of those that cross the BBB. In the progressive forms of MS, however, other cells, such as microglia and astrocytes, are believed to exert an important role and are now regarded as possible treatment targets [55]. New drug categories, such as putative neuroprotective agents, remyelination or neural repair agents are currently under investigation (Tables 1,2).

\subsection{Immune Modulation}

Since the first DMT was released in 1993, many other immunomodulatory drugs have been tested in both RRMS and progressive MS. Clinical trials of beta-interferons and glatiramer acetate in the progressive stages have provided mixed results and overall have not shown clear efficacy in preventing disability. In 2000, mitoxantrone was approved for SPMS after the findings of the MIMS trial showed that the active arm experienced a decreased relapse rate and disability progression. These effects were at least partially driven by the anti-inflammatory effect of mitoxantrone [56]. Currently, the use of mitoxantrone has been abandoned in many countries because of concerns over safety $[57,58]$. However, a short time course of mitoxantrone might be useful in very active MS as an induction treatment, with an acceptable safety profile [59-61]. The immunosuppressants azathioprine, cyclosporine, cyclophosphamide and methotrexate have been also trialled in both RRMS and progressive MS, leading to negative or inconclusive results. More details about these drugs have been extensively reported elsewhere [24, 62-64]. We describe here the agents that have been tested most recently in progressive MS, with a particular focus on SPMS (Table 3).

\subsubsection{Negative Trials}

4.1.1.1 Alemtuzumab Alemtuzumab is a chimeric monoclonal antibody targeting the CD52 surface protein mainly expressed by B and T lymphocytes [65]. A small phase II 


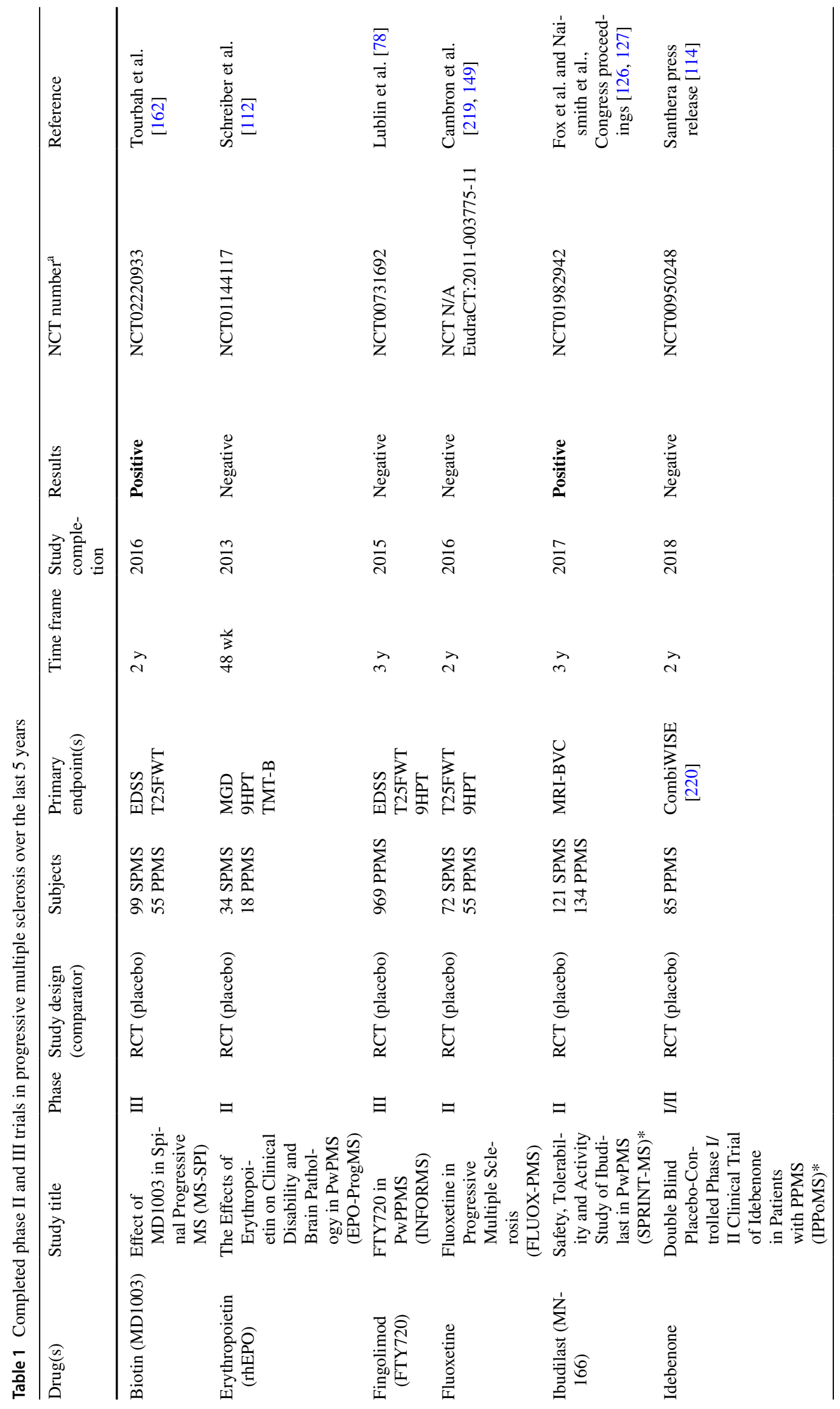




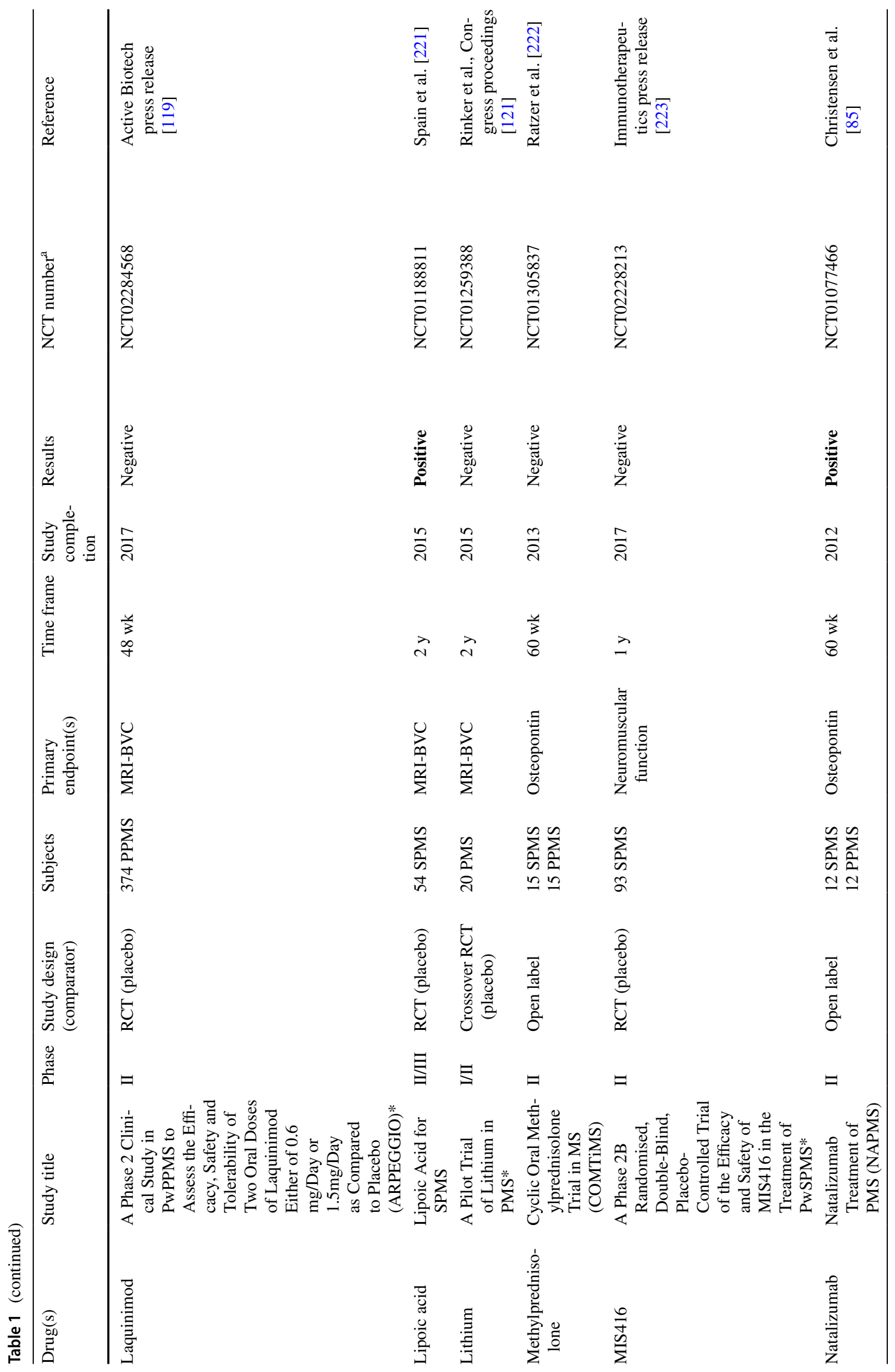




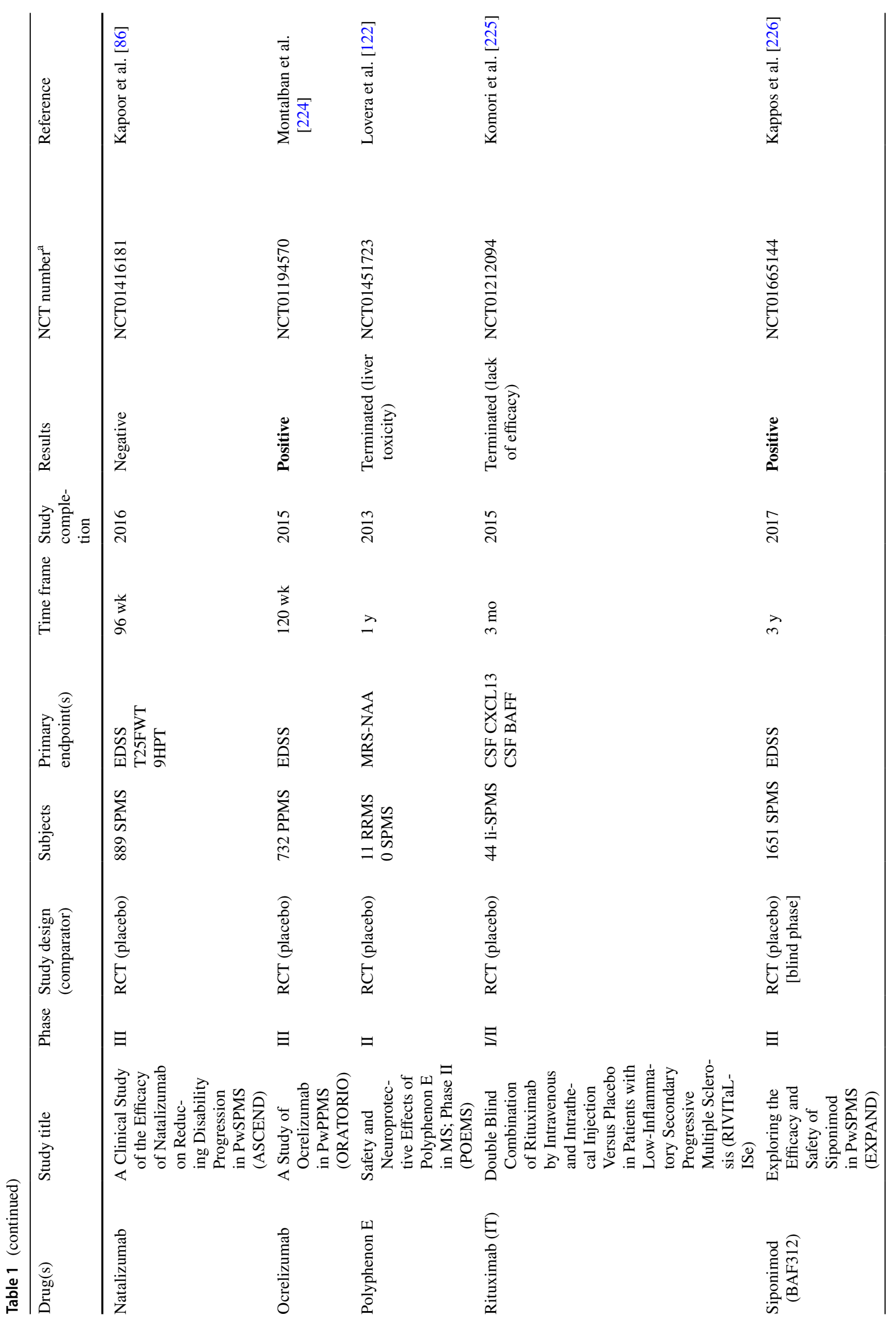


trial with 36 subjects with SPMS attempted CD52-lymphocyte depletion with alemtuzumab [66]. The study showed that patients relentlessly accrued clinical disability and MRI evidence of cerebral atrophy $[67,68]$.

4.1.1.2 Cladribine Cladribine is a synthetic deoxyadenosine analogue chemotherapy agent that is activated by intracellular phosphorylation in specific cell types, such as lymphocytes. Cladribine phosphates interfere with deoxyribonucleic acid synthesis and repair in lymphocytes inducing their death and resulting in a targeted reduction of circulating lymphocytes $[69,70]$. Cladribine showed no efficacy on slowing disability progression and decreasing brain atrophy rates in a placebo-controlled trial in 159 patients with progressive MS, although some previous results from a small phase II trial had suggested positive effects [71-73].

4.1.1.3 Dirucotide Negative results were also obtained with dirucotide (MBP8298), a myelin basic protein capable of inactivating autoreactive $\mathrm{T}$ and $\mathrm{B}$ cells and restoring self-tolerance. Indeed, after a preliminary small trial showing that dirucotide significantly delayed clinical progression in patients expressing the allele HLA-DR2/DR4, two phase III trials, MAESTRO-01 and MAESTRO-03, were commenced in patients with SPMS carrying the specific allele. In MAESTRO-1, dirucotide did not provide a clinical benefit compared to placebo and this led to the decision to terminate the MAESTRO-03 trial early [74, 75].

4.1.1.4 Fingolimod Amongst the DMTs approved for RRMS, fingolimod (FTY720) is an antagonist of the sphingosine-1-phosphate receptors that works by preventing lymphocytes egressing from lymphoid tissues into circulation and then migrating to the CNS. Fingolimod can cross the $\mathrm{BBB}$ and inhibits astrogliosis. In a clinical trial in RRMS, fingolimod significantly reduced brain volume loss [76, 77]. Fingolimod has been investigated in the large, phase III INFORMS trial in PPMS, showing that there was no difference in the rate of disability progression between the active and placebo arms [78].

4.1.1.5 MIS416 MIS416 is a bacterial-derived microparticle capable of stimulating the innate immune system response [79]. Initially used for compassionate use in a few patients with SPMS in New Zealand, the drug was found to be safe and well tolerated in animal models of MS and in 19 patients with SPMS in a non-randomised phase Ib/IIa openlabel trial [80]. A further randomised, placebo-controlled phase IIb trial, however, did not show efficacy of MIS416 in the recruited 90 people with SPMS [79, 81].

4.1.1.6 Natalizumab Natalizumab is a monoclonal antibody that targets the $\alpha 4$ subunit of the very late activation- 4 


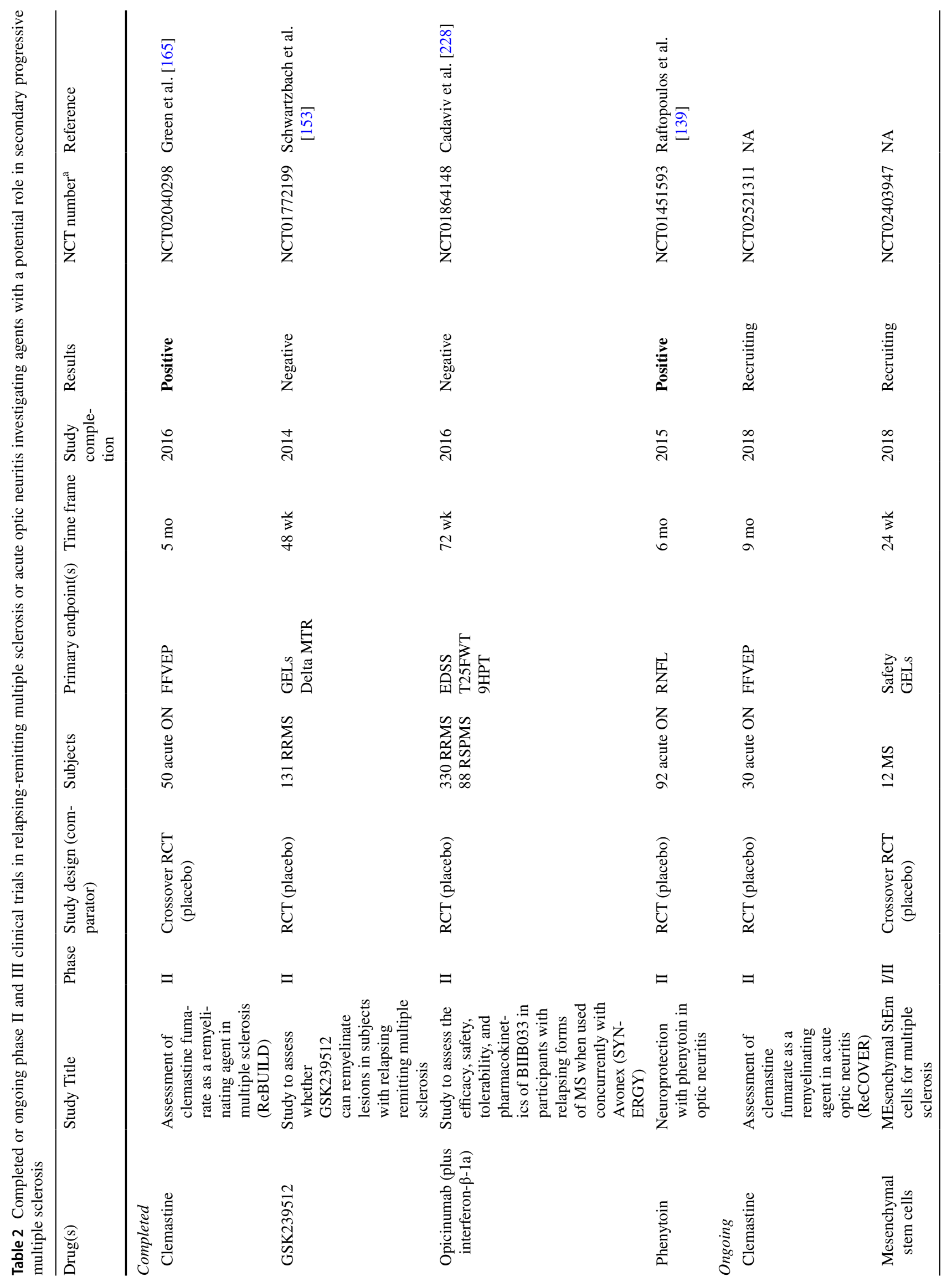




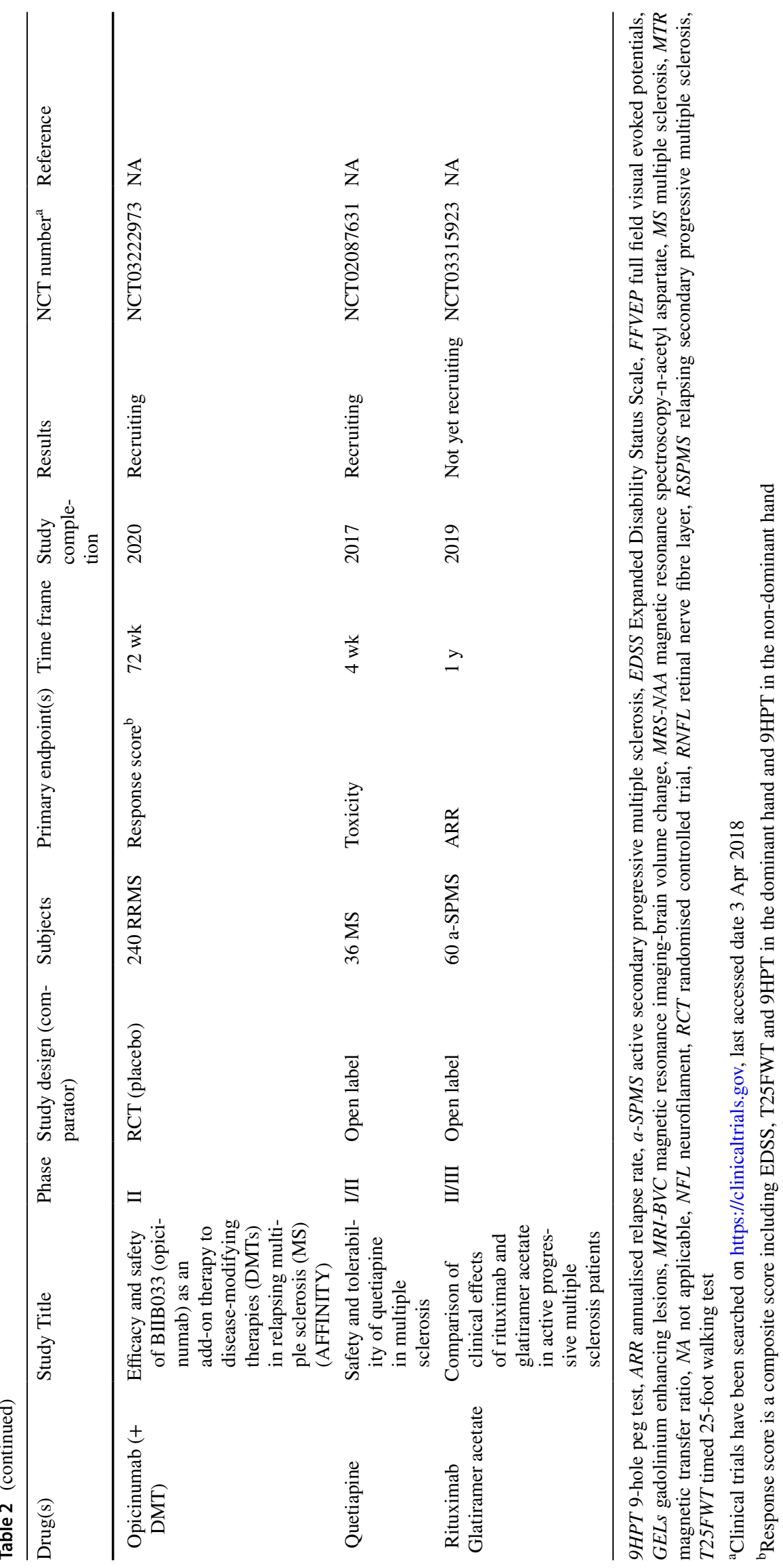




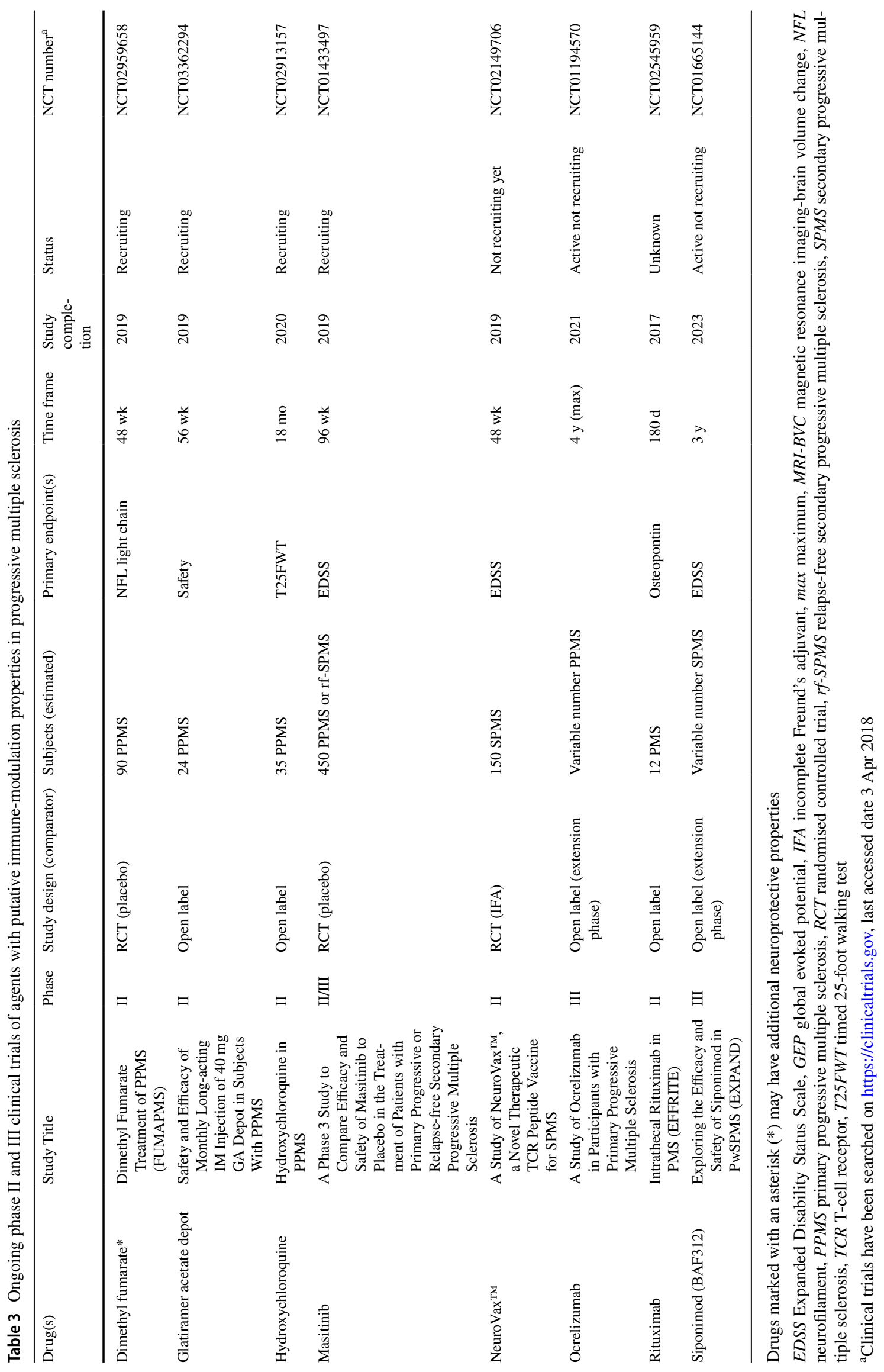


molecule on leucocytes, which blocks the transmigration of systemic immune cells to the CNS reducing inflammation [82-84]. In a small, phase II open-label trial, natalizumab was associated with a decrease of osteopontin, a marker of neuronal damage, in progressive MS [85]. However, in the recently published, phase III ASCEND trial, no treatment effect was observed on the primary outcome, a composite score combining the EDSS, T25FW test and 9HPT used to measure the proportion of patients with confirmed disability progression over 96 weeks. Looking at the sub-components of the primary outcome, there was, however, a significant $44 \%$ reduction in the relative risk of confirmed upper-limb disability progression as measured by the 9 HPT $[15 \%$ with natalizumab vs. $23 \%$ with placebo; adjusted odds ratio 0.56 (95\% confidence interval [CI] 0.40-0.80); $p=0.001$ ] [86].

4.1.1.7 Sulfasalazine The anti-inflammatory and immunemodulator sulfasalazine, used as a DMT for rheumatoid arthritis, showed some efficacy in improving the outcomes of experimental allergic encephalomyelitis (EAE) and showed remyelination properties in animal models. However, it did not prevent the accumulation of clinical disability in active RRMS and progressive MS [87, 88].

\subsubsection{Positive Trials or Promising Results}

4.1.2.1 Rituximab and Ocrelizumab In 2008, the phase II HERMES trial showed that rituximab, a B-cell-depleting chimeric anti-CD20 monoclonal antibody, significantly reduced the number of GELs and the number of relapses in RRMS when compared with placebo [89]. These findings changed the traditional view of MS pathophysiology as an inflammatory disorder principally mediated by $\mathrm{T}$ cells. Rituximab was later investigated in progressive MS, namely in the OLYMPUS [90] and RIVITaLISe [91] trials. Both these studies reported negative results. RIVITaLISe was terminated early, after an interim analysis showing a lower-than-expected depletion of intrathecal B cells that would have been insufficient to translate to potential clinical efficacy in a small phase II trial. In a subgroup of younger patients with active inflammatory lesions from OLYMPUS, selective B-cell depletion could reduce disease progression.

The findings from the OLYMPUS trial had a significant impact on further research and served as a rationale for testing ocrelizumab, another CD20 monoclonal antibody, in both RRMS and PPMS. The OPERA I and OPERA II phase III trials provided the evidence of ocrelizumab as a more effective drug over interferon- $\beta$ in RRMS [92]. In the PPMS ORATORIO trial, patients taking ocrelizumab showed lower rates of 12-week confirmed disability progression (primary outcome) vs. placebo with a relative risk reduction of $24 \%$. Eligibility criteria for ORATORIO included younger age (less than 55 years), evidence of CSF immunoglobulin G oligoclonal bands, and disease duration no longer than 10 or 15 years according to the EDSS. Ocrelizumab has received a licence from the Food and Drug Administration and European Medicines Agency in PPMS.

4.1.2.2 Siponimod Recent encouraging results have been reported from the phase III EXPAND trial that is investigating the efficacy of siponimod (BAF312) in more than 1651 patients with SPMS (siponimod $n=1105$ vs. placebo $n=$ 546). Siponimod can cross the BBB, reduce CNS inflammation, and promote mechanisms of repair via modulation of sphingosine-1-phosphate on astrocytes and sphingosine-1-phosphate receptor 5 on oligodendrocytes [93, 94]. Results from the core study showed that siponimod reduced the risk of 3-month confirmed disability progression by $21 \%$ compared with placebo (hazard ratio $0.79,95 \%$ CI 0.65 $0.95 ; p=0.013)$. The increase in $\mathrm{T} 2$ lesion volume from baseline was significantly lower with siponimod than with placebo (between-group difference $-695.3 \mathrm{~mm}^{3}, 95 \% \mathrm{CI}-$ 877.3 to $-513.3 ; p<0.0001)$. Brain volume was preserved to a higher degree in the siponimod group than in the placebo group (mean percentage change over months 12 and $240.15 \%, 95 \%$ CI $0.07-0.23 ; p=0.0002$ ). Siponimod did not reduce the time to 3-month confirmed worsening of the $\mathrm{T} 25 \mathrm{FW}$ test, the key secondary outcome (hazard ratio 0.94 , $95 \%$ CI $0.80-1.10$; risk reduction $6 \%$; $p=0.44$ ) $[95,96]$.

\subsubsection{Autologous Haematopoietic Stem Cell Transplanta-} tion Autologous haematopoietic stem cell transplantation (AHSCT) induces an initial profound immunosuppression followed by a sub-sequent reconstitution of a qualitatively different immune system. This phenomenon might halt the progression of neurological disability and induce a prolonged medication-free interval. Muraro et al. reported the longterm results of a multicentre, observational, retrospective cohort study on AHSCT [97]. Progression-free survival in the subgroup with relapsing MS was 73\% (95\% CI 57-88\%) at 5 years after AHSCT. Amongst patients with SPMS, the largest subgroup in the study, 33\% (95\% CI 24-42\%) remained free from EDSS score deterioration with a rate of mortality of $2.8 \%$. A recent meta-analysis has reported an increased risk of mortality in progressive patients with high EDSS scores undergoing AHSCT and a favourable effect in RRMS reaching levels of 'no evidence of disease activity' comparable to those reported from DMTs. This findings suggest that AHSCT may be a more effective alternative to approved DMTs in selected patients [98]. A phase III randomised trial is currently recruiting participants to assess the relative role of AHSCT vs. alemtuzumab in adults with RRMS no older than 50 years of age, with an EDSS score of $\leq 5.5$ and the presence of significant inflammatory disease activity in the last year despite treatment with standard DMTs (NCT03477500). 


\subsubsection{Ongoing Trials}

4.1.3.1 Dimethyl Fumarate Dimethyl fumarate (DMF) may have a role in the treatment of progressive MS given its anti-inflammatory and neuroprotective properties $[99,100]$. Strassburger-Krogias and colleagues carried out an observational study in 26 patients with progressive MS (12 PPMS, 14 SPMS) treated with the fumarate mixture Fumaderm ${ }^{\circledR}$, approved for psoriasis in Germany, or DMF by pharmaceutical preparation [101]. They found no disease progression in more than $75 \%$ of the treated patients after a mean follow-up period of about 15 months. In 2015, the phase III, randomised controlled trial INSPIRE was started to further investigate the effects of DMF in SPMS. Because of the failure of the similarly designed ASCEND study, INSPIRE was terminated early. However, the phase II study FUMAPMS is currently recruiting participants to assess the efficacy of DMF in decreasing the neurofilament light chain, a marker of neuronal damage, in 90 patients with PPMS after 48 weeks (NCT02959658).

4.1.3.2 Masitinib Masitinib can inhibit mast cell activation. Migration and degranulation of mast cells in the CNS release proinflammatory and vasoactive mediators, which actively participate in the pathogenesis of MS [102, 103]. Masitinib is being investigated in a phase II/III randomised controlled trial assessing its safety and efficacy in lowering clinical disability in 450 people with PPMS and relapsefree SPMS (NCT01433497) [104]. In a previous, pilot phase II study in 12 subjects with PPMS and 18 subjects with relapse-free SPMS, masitinib showed some therapeutic benefits on reducing the rate of upper and lower limb function impairment [105].

\subsection{Neuroprotection}

Several mechanisms can be addressed to achieve neuroprotection. As reported by neuropathology studies, MS shows neuroaxonal loss at any stage of the disease, with a preponderance in the progressive courses $[6,106]$. A number of studies are currently investigating putative neuroprotective agents in progressive and relapsing MS (Table 4).

\subsubsection{Negative Trials}

4.2.1.1 Dronabinol Dronabinol is a cannabinoid that showed experimental evidence for neuroprotective effects [107]. Dronabinol was investigated in the placebo-controlled CAMS study looking for anti-spasticity effects. The CAMS study was negative, but it incidentally showed that patients with a progressive course had alleviation of symptoms [108]. Dronabinol was then tested in the phase III CUPID trial, which did not show a benefit of dronabinol on the progression rate or in decreasing rates of brain volume loss. The unexpected low progression rate in the placebo arm may have affected the results [109].

4.2.1.2 Erythropoietin Erythropoietin can stimulate brain neuroprotection in experimental studies, promoting axonal repair, neurogenesis and angiogenesis [110]. After a pilot study in chronic progressive MS, Schreiber and colleagues undertook a randomised, placebo-controlled phase II trial of high-dose recombinant human erythropoietin in 52 patients with progressive MS (34 had SPMS and 18 PPMS). They reported that erythropoietin did not improve the change in a composite measure of maximum gait distance, hand dexterity and cognition from baseline to 24 weeks $[111,112]$.

4.2.1.3 Idebenone Idebenone is a coenzyme $\mathrm{Q} 10$ analogue with antioxidant properties. Idebenone can decrease reactive oxygen species contributing to the maintenance of a normal neuronal energy state [113]. A phase I/II adaptive study, the IPPoMS trial, had been recently reported showing no difference between the active treatment group and placebo in the rate of disability progression in the 77 randomised patients with PPMS [114]. An open-label safety and efficacy extension of the IPPoMS trial has been undertaken (NCT00950248 and NCT01854359). Full results are not available yet [114].

4.2.1.4 Lamotrigine Lamotrigine, licenced as an anticonvulsant, is thought to exert neuroprotective properties by the blockade of sodium channels. In a phase II trial, lamotrigine failed to show a reduction in brain atrophy rates over placebo in patients with SPMS. It was speculated that the results were affected by a high rate of non-adherence in the lamotrigine arm and by decreased brain volume during the first year of study likely owing to pseudoatrophy. This is a phenomenon characterised by an apparent brain volume reduction, whose mechanisms can include fluid shifts or oedema resolution after the commencement of drugs with potent anti-inflammatory effects $[115,116]$.

4.2.1.5 Laquinimod Laquinimod is another drug that has shown some neuroprotective properties in preclinical studies [117]. The phase II proof-of-concept ARPEGGIO trial, however, did not reduce MRI-derived brain atrophy or the rate of confirmed disability progression over 48 weeks in PPMS (NCT02284568) [118, 119].

4.2.1.6 Lithium Lithium is a mood-stabilising drug that exerts anti-inflammatory effects and has shown some potential in reducing progression in animal models of several neurodegenerative diseases [120]. Rinker and colleagues reported the results from a 2-year open-label crossover trial of adjunctive low-dose lithium carbonate vs. standard care 
Table 4 Ongoing phase II and III clinical trials of agents with putative neuroprotective properties in progressive multiple sclerosis

\begin{tabular}{|c|c|c|c|c|c|c|c|c|c|}
\hline Drug(s) & Title & Phase & Study design & $\begin{array}{l}\text { Subjects } \\
\text { (estimated) }\end{array}$ & $\begin{array}{l}\text { Primary } \\
\text { endpoint(s) }\end{array}$ & Time frame & $\begin{array}{l}\text { Study } \\
\text { comple- } \\
\text { tion }\end{array}$ & Status & NCT number ${ }^{\mathrm{a}}$ \\
\hline $\begin{array}{l}\text { Andro- } \\
\text { grapholides }\end{array}$ & $\begin{array}{l}\text { Efficacy, } \\
\text { safety and } \\
\text { tolerability } \\
\text { of andro- } \\
\text { grapholides } \\
\text { versus } \\
\text { placebo in } \\
\text { patients with } \\
\text { progressive } \\
\text { forms of MS }\end{array}$ & $\mathrm{I} / \mathrm{II}$ & $\begin{array}{l}\text { RCT (pla- } \\
\text { cebo) }\end{array}$ & 68 PMS & MRI-BVC & $2 \mathrm{y}$ & 2017 & Unknown & NCT02273635 \\
\hline $\begin{array}{l}\text { Amiloride } \\
\text { Fluoxetine } \\
\text { Riluzole }\end{array}$ & $\begin{array}{l}\text { MS secondary } \\
\text { progressive } \\
\text { multi arm } \\
\text { randomisa- } \\
\text { tion trial } \\
\text { (MS- } \\
\text { SMART) }\end{array}$ & II & $\begin{array}{l}\text { Multi-arm } \\
\text { RCT (pla- } \\
\text { cebo) }\end{array}$ & 445 SPMS & MRI-BVC & 96 wk & 2018 & $\begin{array}{l}\text { Active, not } \\
\text { recruiting }\end{array}$ & NCT01910259 \\
\hline Lipoic acid & $\begin{array}{l}\text { Lipoic acid for } \\
\text { progressive } \\
\text { MS }\end{array}$ & II & $\begin{array}{l}\text { RCT (pla- } \\
\text { cebo) }\end{array}$ & 118 PMS & T25FWT & $2 \mathrm{y}$ & 2021 & $\begin{array}{l}\text { Not yet } \\
\text { recruiting }\end{array}$ & NCT03161028 \\
\hline $\begin{array}{l}\text { Oxcarbaz- } \\
\text { epine }\end{array}$ & $\begin{array}{l}\text { Protective role } \\
\text { of oxcarbaz- } \\
\text { epine in MS } \\
\text { (PROXI- } \\
\text { MUS) }\end{array}$ & II & $\begin{array}{l}\text { RCT (pla- } \\
\text { cebo) }\end{array}$ & $\begin{array}{r}30 \text { SPMS/ } \\
\text { PRRMS }\end{array}$ & $\begin{array}{l}\text { NFL light } \\
\text { chain }\end{array}$ & 48 wk & 2018 & Recruiting & NCT02104661 \\
\hline Simvastatin & $\begin{array}{l}\text { Multiple } \\
\text { sclerosis- } \\
\text { Simvastatin } \\
\text { trial } 2 \text { (MS- } \\
\text { STAT2) }\end{array}$ & III & $\begin{array}{l}\text { RCT (pla- } \\
\text { cebo) }\end{array}$ & 1180 SPMS & EDSS & $182 \mathrm{wk}$ & 2023 & Recruiting & NCT03387670 \\
\hline
\end{tabular}

EDSS Expanded Disability Status Scale, $M R I-B V C$ magnetic resonance imaging-brain volume change, $M S$ multiple sclerosis, $N F L$ neurofilament, PPMS primary PMS, PRRMS progressive relapsing-remitting MS, RCT randomised controlled trial, SPMS secondary PMS, T25FWT timed 25-foot walking test

${ }^{\mathrm{a} C l i n i c a l}$ trials have been searched on https://clinicaltrials.gov, last accessed date 3 Apr 2018

in 23 patients with progressive MS (3 PPMS and 20 SPMS). Subjects were randomly assigned to take lithium daily in year 1 or 2 . Primary outcome measures were safety, tolerability and change in brain parenchymal fraction. Preliminary results showed a non-statistically significant decrease in brain atrophy over 1 year (brain parenchymal fraction increased by a mean of $0.560 \pm 0.379 \%$, compared to 0.139 $\pm 0.304 \%$ during standard care; $p=0.399$ ). Relapse rates and change in EDSS did not significantly differ between onand off-lithium time periods. The authors concluded that low-dose lithium was well tolerated and that a preliminary analysis could not rule out a benefit on brain volume compared to standard care [121]. Full publication is pending.

4.2.1.7 Polyphenon E Polyphenon E is a natural antioxidant agent capable of reducing oxidative stress in mitochondrial and consequent axonal injury. In 2011, the phase II POEMS study opened the recruitment to assess the safety and the neuroprotective effects of Polyphenon E in MS. Unexpectedly, Polyphenon E caused liver toxicity and the trial was terminated [122].

\subsubsection{Positive Trials or Promising Results}

4.2.2.1 Ibudilast Ibudilast (MN166-001) has anti-inflammatory actions, and inhibits nitric oxide synthesis and tumour necrosis factor- $\alpha$, which is released by activated astrocytes and microglia [123, 124]. In a phase II, randomised placebo-controlled trial in RRMS, ibudilast was not effective in decreasing the number of relapses or new MRI lesions, but significantly reduced brain atrophy after 2 years [125]. Based on these results, the phase II SPRINTMS study recruited 255 patients with progressive MS and tested the efficacy of ibudilast against placebo in reducing 
the rate of MRI-derived brain atrophy over 96 weeks. Preliminary results showed that treatment with ibudilast was associated with a $48 \%$ slowing in the rate of brain atrophy (atrophy rate for ibudilast: $-0.00105 ; 90 \% \mathrm{CI}-0.00160$, -0.00049 ; atrophy rate for placebo: $-0.00202 ; 90 \%$ CI $0.00256,-0.00147)[126,127]$.

4.2.2.2 Lipoic Acid Lipoic acid is an antioxidant promoting free-radical scavenging, metallic ion chelation, regeneration of intracellular glutathione and oxidative damage repair of macromolecules. It also takes part in the mitochondrial oxidative respiration and nucleic acid synthesis, and inhibits macrophage and microglial activation in $\operatorname{EAE}[128,129]$. Spain and colleagues presented the results of a phase II study investigating lipoid acid in SPMS [130]. They showed that, after 2 years, participants taking lipoic acid had significantly less annualised percentage of brain volume change $(-0.21 \%$, standard error of the estimate $=0.14)$ than controls $(-0.65 \%$, standard error of the estimate $=0.10, \mathrm{p}=$ 0.002 ). The beneficial effect size of lipoic acid treatment corresponded to a $0.44 \pm 0.29 \%$ improvement in the rate of whole-brain atrophy (95\% CI 0.157-0.727).

4.2.2.3 Minocycline Minocycline is a tetracycline antibiotic with immunomodulatory and neuroprotective properties capable of crossing the BBB, preventing microglial activation, glutamate excitotoxicity and apoptosis [131, 132]. Evidence supporting the neuroprotective role of minocycline has emerged from experimental models of acute neuronal injury (stroke, brain and spinal cord trauma), chronic neurodegenerative diseases (amyotrophic lateral sclerosis, Huntington's disease) and autoimmune CNS inflammation [131, 133]. An open-label study of interferon- $\beta$ and minocycline in ten people with active RRMS showed positive effects on disease inflammation, decreasing the total number of GELs; whereas no superiority was found in decreasing the number of GELs in the combination therapy of minocycline with glatiramer acetate or interferon- $\beta 1-\mathrm{a}$ vs. injectable monotherapies in two double-blind, placebo-controlled phase II studies [134-136]. More recently, a study of minocycline vs. placebo in 142 patients with CIS suggested that minocycline may delay the conversion to MS [137]. The neuroprotective role of minocycline has not been investigated in progressive MS yet and whether this drug may have a role in the future trials in progressive MS is currently unknown.

4.2.2.4 Phenytoin Phenytoin, similarly to oxcarbazepine, is a selective sodium-channel inhibitor with neuroprotective properties [138]. In a randomised phase II trial of 58 subjects with acute optic neuritis, the adjusted mean difference (i.e. phenytoin group minus placebo group) of the RNFL in the affected eye was $7.15 \mu \mathrm{m}$ (95\% CI 1.08-13.22; $p=$ 0.021 ) after 6 months. This result corresponded to a $30 \%$ reduction in the extent of RNFL loss with phenytoin compared with placebo, showing potential neuroprotection of the optic nerve [139]. Phenytoin has not yet been tested in progressive MS.

4.2.2.5 Simvastatin Simvastatin is used for the treatment of primary hyperlipidaemia and secondary prevention of myocardial or cerebral ischaemia. Experimental evidence, however, suggested that statins can also exert anti-inflammatory and protective properties in the CNS. After some contradictory results from trials in RRMS, the phase II MS-STAT trial was undertaken investigating the effect of high-dose simvastatin vs. placebo in reducing brain atrophy rate in 140 patients with SPMS over 2 years. They found that simvastatin significantly reduced the annualised MRI-derived brain atrophy rate by $43 \%$ (adjusted difference in atrophy rate between the groups: $-0.254 \%$; $95 \% \mathrm{CI}-0.422$ to $0.087 ; p=0.003$ ) [140]. In the cognitive sub-study of the MS-STAT trial, there was evidence of a positive effect of simvastatin on frontal lobe function (difference 1.2 points, 95\% CI 0.2-2.3 between baseline and month 24) and on the physical component of a quality-of-life measure (difference 2.5 points, 95\% CI 0.3-4.8; $p=0.028$ ) [141]. Following these positive results, the phase III study MS-STAT2 will shortly start the recruitment of 1180 patients with SPMS in the UK. MS-STAT2 will assess the time to confirmed disability progression between simvastatin and placebo arm as measured by the EDSS after 36 months (NCT03387670).

\subsubsection{Ongoing Trials}

4.2.3.1 Amiloride, Fluoxetine and Riluzole The MSSMART trial is a multi-arm, phase II placebo-controlled study investigating the putative neuroprotection properties of amiloride, fluoxetine and riluzole in 445 patients with SPMS [142]. Amiloride is an acid-sensing ion channel-1 blocker. Recent studies have shown that acid-sensing ion channel-1 contribute to axonal degeneration in CNS lesions. In MS, acid-sensing ion channel-1 seem to activate under acidic conditions predominating in the inflammatory CNS lesions, leading to a $\mathrm{Na}^{+}$and $\mathrm{Ca}^{2+}$ overload and resulting damage and apoptosis of axons [143]. A pilot open-label study in 14 patients with PPMS showed that amiloride significantly reduced the rate of MRI-derived brain atrophy [144]. The same research group and independently an Austrian team investigated the effect of amiloride in patients with acute optic neuritis [145]. The former study showed no neuroprotective benefits. A report of the results from the latter has not been presented yet (NCT01879527).

Fluoxetine is a selective serotonin-reuptake inhibitor with pleiotropic neuroprotective effects stimulating glycogenolysis and improving mitochondrial energy metabolism $[146,147]$. Mostert and colleagues carried out a pilot 2-year 
randomised, placebo-controlled phase II trial in 42 people with progressive MS (29 SPM and 13 PPMS) and showed no evidence of a significant clinical benefit [148]. However, this study had a low sample size and the same research team carried out a further trial in progressive MS, using as a primary outcome measure the time to confirmed disease progression defined as either at least a $20 \%$ increase in the T25FW test or at least a $20 \%$ increase in the 9-HPT. They reported a trend ( $p=0.07)$ towards a significant difference in time to confirmed disease progression between fluoxetine and placebo groups. Magnetic resonance imaging results are expected. It was speculated that the study was underpowered to detect a significant clinical effect over the 2 years of the trial [149].

Riluzole antagonises voltage-dependent sodium channels and is a glutamate receptor modulator that inhibits the synaptic release of glutamate, which is a neurotoxic agent. A pilot study of riluzole in PPMS showed a reduction in the rate of cervical cord atrophy and the number of new brain $\mathrm{T} 1$ hypointense lesions [150]. Waubant and colleagues investigated the neuroprotective effect of riluzole vs. placebo in patients with early RRMS as an add-on to interferon- $\beta-1 \mathrm{a}$. They reported no difference between placebo and riluzole on brain atrophy as measured by MRI [151].

4.2.3.2 Oxcarbazepine Oxcarbazepine may have neuroprotective properties by blocking sodium channels. Oxcarbazepine is being investigated in the PROXIMUS study, a phase IIa trial that recruited patients in the early stage of SPMS who were still receiving DMTs. The rationale behind this study is the attempt to treat SPMS addressing both neurodegeneration with oxcarbazepine and inflammation with approved DMTs. Quantification of the CSF neurofilament light chain is the primary outcome measure of the trial (NCT02104661).

\subsection{Regenerative Therapies}

This therapeutic approach to MS is new and a number of agents are currently being investigated (Table 5).

\subsubsection{Negative Trials}

4.3.1.1 GSK239512 GSK239512 is a selective and brain penetrant, histamine $\mathrm{H}_{3}$ receptor antagonist capable of promoting oligodendrocyte progenitor cell differentiation in vitro and enhances remyelination in the cuprizone mouse model of remyelination [152]. In a pilot placebo-controlled phase II study, GSK239512 had a good safety profile and a small positive effect on remyelination as measured by MTR in a cohort of 131 patients with RRMS, although there was no effect on clinical or conventional MRI parameters. It was speculated that the development of clinical endpoints more directly linked to changes in myelination or the inclusion of a population with more disease activity, or a longer trial duration would have been more appropriate to explore the impact of GSK239512 on the disease [153].

4.3.1.2 Opicinumab Not formally assessed in patients with progressive MS, the human monoclonal antibody opicinumab (BIIB033 or anti-LINGO-1) has shown remyelination and neuroprotective properties in animal models of MS [154-157]. In the phase II RENEW trial, 82 participants with acute optic neuritis were randomised to receive opicinumab or placebo. The primary endpoint was remyelination at 24 weeks, measured as the recovery of affected optic nerve conduction latency using full-field VEP vs. the unaffected fellow eye at baseline. Remyelination did not differ significantly between the opicinumab and placebo groups in the intention-to-treat population at week 24. However, results from the pre-specified per-protocol population at week 24 [14.7 vs. 22.2 ( -15.1 to 0.0$) ; 34 \% ; p=0.050$ ] suggested that opicinumab could enhance remyelination in the human CNS [158]. SYNERGY was a phase II study investigating the additive efficacy of opicinumab to interferon- $\beta-1 \mathrm{a}$ in patients with RRMS. Preliminary results showed that the trial did not meet the pre-specified primary endpoint [159]. The phase II AFFINITY trial is ongoing to evaluate the effects of opicinumab, as an add-on therapy to anti-inflammatory DMTs, on disability improvement over 72 weeks in relapsing MS (NCT03222973).

\subsubsection{Positive Trials or Promising Results}

4.3.2.1 Biotin Biotin (MD1003) can increase energy production in demyelinated axons and enhance myelin synthesis in oligodendrocytes, behaving as both a neuroprotective and myelin repair drug [160]. After an open-label pilot study of biotin in 23 patients with progressive MS (both SPMS and PPMS) showed that patients had a qualitative or quantitative improvement, Tourbah et al. reported the results of the MS-SPI trial. The primary endpoint was the proportion of patients with an improvement of MS-related disability (measured with EDSS or T25FW) at month 9, confirmed at month 12. They found an improvement in MS-related disability at month 9 , confirmed at month 12 , in $12.6 \%$ of the patients, and a reduced proportion of patients with EDSS at month 9 (confirmed at month 12) [161, 162]. Interestingly, an MRI sub-study of the trial showed an improvement in MTR and fractional anisotropy on diffuse tensor imaging, markers of myelin density and axonal integrity, respectively, and a reduction in whole brain volume and grey matter volume. The decrease in brain volume was perhaps the result of pseudoatrophy [163]. Further results from the placebocontrolled crossover MS-ON trial of biotin in patients with progressively worsening optic neuritis did not meet the primary outcome-a mean change in $100 \%$ contrast visual 
Table 5 Ongoing phase II and III clinical trials of agents with putative regenerative properties in progressive multiple sclerosis

\begin{tabular}{|c|c|c|c|c|c|c|c|c|c|}
\hline Drug(s) & Title & Phase & Study design & $\begin{array}{l}\text { Subjects (esti- } \\
\text { mated) }\end{array}$ & $\begin{array}{l}\text { Primary } \\
\text { endpoint(s) }\end{array}$ & Time frame & End & Status/results & NCT number ${ }^{a}$ \\
\hline ACTH* & $\begin{array}{l}\text { ACTH in } \\
\text { progressive } \\
\text { forms of } \mathrm{MS}\end{array}$ & II & RCT (placebo) & 100 PMS & T25FWT & $3 y$ & 2022 & Recruiting & NCT01950234 \\
\hline $\mathrm{ABMT}^{*}(\mathrm{IV})$ & $\begin{array}{l}\text { Assessment of } \\
\text { bone marrow- } \\
\text { derived cel- } \\
\text { lular therapy } \\
\text { in PMS } \\
\text { (ACTiMuS) } \\
\text { [229] }\end{array}$ & II & $\begin{array}{l}\text { Crossover RCT } \\
\text { (placebo) }\end{array}$ & $\begin{array}{l}60 \text { SPMS } \\
20 \text { PPMS }\end{array}$ & GEP & $2 \mathrm{y}$ & 2018 & Recruiting & NCT01815632 \\
\hline $\begin{array}{l}\text { Biotin } \\
\text { (MD1003) }\end{array}$ & $\begin{array}{l}\text { Effect of } \\
\text { MD1003 in } \\
\text { PMS (SPI2) }\end{array}$ & III & Placebo & 600 PMS & $\begin{array}{l}\text { EDSS } \\
\text { T25FWT }\end{array}$ & $15 \mathrm{mo}$ & 2019 & Recruiting & NCT02936037 \\
\hline Domperidone & $\begin{array}{l}\text { Domperidone } \\
\text { in SPMS }\end{array}$ & II & Open label & 62 SPMS & T25FWT & $1 \mathrm{y}$ & 2020 & Recruiting & NCT02308137 \\
\hline $\begin{array}{l}\text { Mesenchymal } \\
\text { stem cells }\end{array}$ & $\begin{array}{l}\text { Optimal } \\
\text { administra- } \\
\text { tion mode of } \\
\text { autologous } \\
\text { mesenchymal } \\
\text { bone marrow } \\
\text { stem cells in } \\
\text { active and } \\
\text { progressive } \\
\text { multiple } \\
\text { sclerosis }\end{array}$ & II & $\begin{array}{l}\text { Randomised } \\
\text { (different } \\
\text { administra- } \\
\text { tion) }\end{array}$ & 36 PMS & $\begin{array}{l}\text { MRI-BVC } \\
\text { Immunological } \\
\text { response }\end{array}$ & $1 \mathrm{y}$ & 2018 & Recruiting & NCT02166021 \\
\hline $\begin{array}{l}\text { Mesenchy- } \\
\text { mal stem } \\
\text { cell-derived } \\
\text { neural pro- } \\
\text { genitors }\end{array}$ & $\begin{array}{l}\text { Intrathecal } \\
\text { adminis- } \\
\text { tration of } \\
\text { autologous } \\
\text { mesenchy- } \\
\text { mal stem } \\
\text { cell-derived } \\
\text { neural } \\
\text { progenitors } \\
\text { (MSC-NP) } \\
\text { in progres- } \\
\text { sive multiple } \\
\text { sclerosis }\end{array}$ & II & $\begin{array}{l}\text { Crossover RCT } \\
\text { (placebo) }\end{array}$ & 50 PMS & EDSS-Plus & $27 \mathrm{mo}$ & 2023 & Recruiting & NCT03355365 \\
\hline
\end{tabular}

Drugs marked with an asterisk $(*)$ may have also additional immune-modulation properties

$A B M T$ autologous bone marrow transplantation, ACTH adrenocorticotropic hormone, EDSS Expanded Disability Status Scale, GEP global evoked potential, $I V$ intravenous, $M R I-B V C$ magnetic resonance imaging-brain volume change, $M S$ multiple sclerosis, $P P M S$ primary progressive multiple sclerosis, $R C T$ randomised controlled trial, SPMS secondary progressive multiple sclerosis, $T 25 F W T$ timed 25 -foot walking test

${ }^{\mathrm{a}}$ Clinical trials have been searched on https://clinicaltrials.gov, last accessed date 3 Apr 2018

acuity at 6 months [164]. The confirmatory phase III SPI-2 trial is currently recruiting patients with progressive MS (NCT02936037).

4.3.2.2 Clemastine Fumarate Clemastine fumarate promotes oligodendrocyte precursor differentiation and remyelination without modulating the immune system. Green et al. reported the results from the crossover, randomised, placebo-controlled phase II ReBUILD trial, where clemastine fumarate was used in patients showing chronic optic neuritis and evidence of VEP P100 latency of $118 \mathrm{~ms}$ and RNFL $>70 \mu \mathrm{m}$. The primary outcome was a shortening of P100 latency delay on full-field patternreversal VEPs. The primary pre-specified efficacy endpoint for the trial was met with a reduction in latency delay of $1.7 \mathrm{~ms} /$ eye $(95 \%$ CI $0.5-2.9 ; p=0.0048)$ in the crossover model [165]. A new phase II trial on clemastine fumarate in acute optic neuritis is now recruiting aiming at assessing the degree of recovery with or without clemastine (ReCOVER trial, NCT02521311) [166]. 
4.3.2.3 Mesenchymal Stem Cells Mesenchymal stem cells (MSCs) have multipotent mesodermal differentiation potential and can promote tissue repair through the release of paracrine factors. Mesenchymal stem cells can also inhibit gliosis and promote oligodendrogenesis, showing neuroprotection properties. Intravenous administration of MSCs or their derivatives are protective against EAE in mice [167, 168]. Pilot studies have supported the safety or the potential efficacy of MSCs [169-172]. An open-label, phase IIa proof-of-concept study in ten patients with SPMS showed that disease improved on measures of visual function and VEPs, and imaging showed an increase in the optic nerve area [173]. A small, randomised, placebo-controlled, phase II crossover study in nine patients with RRMS suggested a trend to lower cumulative GELs at brain MRI [174]. A recent, phase I open-label trial of an intrathecal, autologous, bone marrow MSC-derived neural progenitor showed good safety and tolerability and suggested possible clinical improvement in patients with progressive MS [175].

\subsubsection{Ongoing Trials}

4.3.3.1 ACTH ACTH used to treat MS relapses acts via corticosteroid-independent melanocortin pathways suppressing CNS proinflammatory cytokines [176]. A randomised clinical trial of ACTH pulse therapy in progressive MS is currently recruiting participants. Safety, tolerability and efficacy of ACTH on a walking test at 36 months will be assessed (NCT01950234). At the same time, a phase IV trial is recruiting patients with RRMS or SPMS to determine if monthly pulsed doses of a 3-day course of ACTH are more effective than one course at recovering myelin at 12 months, as measured by MRI myelin water fraction, in new MS lesions (NCT02446886).

4.3.3.2 Domperidone Domperidone can increase the levels of prolactin, which seems to improve myelin repair in mice. A Canadian group is now leading an open-label, phase II futility trial assessing the efficacy of domperidone in 62 patients with SPMS. This study is currently recruiting participants (NCT02308137) [177].

4.3.3.3 Quetiapine Fumarate Quetiapine fumarate, an atypical antipsychotic, may have remyelination properties [178]. The University of Calgary, in collaboration with the Multiple Sclerosis Society of Canada, is now recruiting patients with RRMS and progressive MS in a phase I/II trial with the purpose to test the safety and dose tolerability of quetiapine (NCT02087631).

4.3.3.4 Triiodothyronine A phase I study is addressing the safety and tolerability of high-dose thyroid hormone (triiodothyronine or T3) as a putative remyelinating drug for MS
(NCT02760056). Indeed, T3 is thought to enhance remyelination in the adult brain by the induction of oligodendrocyte maturation. In cuprizone-induced demyelination mice, T3 promotes remyelination in chronic lesions by both enhancing oligodendrocyte maturation and attenuating astrogliosis [179].

\subsection{Other Approaches}

\subsubsection{Antiviral Therapies}

4.4.1.1 GNbAC1 Human endogenous retroviruses are present in a latent form in the human genome, and in patients with MS. Human endogenous retrovirus-W, known as the MS-associated endogenous retrovirus, can be activated by environmental factors and produces a pathogenic surface envelope protein. This envelope protein can contribute to MS pathogenesis by inducing the activation of proinflammatory macrophages and inhibiting neuronal remyelination. GnbAC1 is a monoclonal antibody directed against this human retroviral protein that appeared to be safe in 33 healthy subjects and ten patients with MS [180, 181]. Recently, $\mathrm{GNbAC} 1$ has been investigated in the randomised, placebo-controlled, phase II CHANGE-MS study in RRMS. The results showed no effect on inflammatory measures (including the number of GELs) over weeks 12-24. However, a post-hoc analysis suggested that GnbAC1 $18 \mathrm{mg} / \mathrm{kg}$ may have remyelination properties according to the increase of MTR values in the cortical grey matter bands [band 3 $\Delta$ MTR between baseline and week 24 was $2.167 \%$ (percentage unit) change, $p=0.059$ ]. Given the evidence of some remyelinating properties, the use of GnbAC1 may be considered for SPMS in the future [182]. Full publication of this study is pending.

\subsubsection{Immunotherapy}

4.4.2.1 ATX-MS-1467 Induction of antigen-specific immune tolerance, or immunisation, is now a feasible approach to autoimmune disorders. ATX-MS-1467 is made of four peptides of a myelin protein commonly attacked in MS. Once injected, the antigens carried by ATX-MS-1467 are taken up by immature antigen-presenting cells, which, instead of inactivating $\mathrm{T}$ cells, convert them to T-cell types that maintain tolerance [183]. In animal models of MS and six patients with SPMS, Streeter et al. have demonstrated that a daily injection of ATX-MS-1467 was well tolerated and led to inhibition of EAE and disease progression [184]. More recently, the results from two open-label phase I studies and a phase IIa proof-of-concept study showed that ATXMS-1467 is safe, well tolerated and potentially effective in RRMS. Indeed, in the phase II study, there was a statistically significant decrease in the number of T1 GELs on treatment 
compared with baseline (from $7.4 \pm 7.62$ to $5.0 \pm 7.24 ; p=$ 0.0143 ) based on a non-parametric analysis [185].

4.4.2.2 NeuroVax ${ }^{\mathrm{TM}}$ Vaccination with the T-cell receptor (TCR) complementarity determining regions 2 (CDR2 peptide-associated beta variable (BV) gene was able to cure EAE [186]. Development of the TCR peptide vaccination for MS required identifying target TCR BV genes and creating a vaccine capable of reliably boosting TCRreactive T cells [187, 188]. Gold et al. performed a small study of vaccination with a TCR BV6S5 CDR2 peptide emulsified in incomplete Freund's adjuvant in MS. They reported no clinical benefit in the immunised patients, but there was evidence of a decreased number of activated BV6S5 T cells within the CNS [189].

Since then, many other TCR BV targets have been used. For instance, in a phase I/II study, Bourdette and co-workers investigated the immunogenicity and safety of combined administration of CDR2 TCR peptides (BV5S2, BV6S5 and BV13S1) emulsified in incomplete Freund's adjuvant. They showed that the trivalent TCR peptide vaccine in incomplete Freund's adjuvant strongly boosted circulating frequencies of TCR-reactive T cells in $100 \%$ of patients with MS (including SPMS and RRMS), whereas a low rate of successful vaccination $(20 \%)$ was found within subjects treated with individual TCR peptides in saline. No statistically significant differences were found in MRI activity between the TCR responder and non-responder groups. However, this study was small, including 37 subjects, and short (24 weeks). A study of NeuroVax ${ }^{\mathrm{TM}}$, a therapeutic TCR peptide vaccine, is currently ongoing in SPMS (NCT02057159).

4.4.2.3 Tcelna $^{\mathrm{TM}}$ Tcelna $^{\mathrm{TM}}$ (previously known as Tovaxin) is an autologous T-cell immunotherapy consisting of in-vitro expanded myelin-reactive $T$ cells manufactured against up to six immunodominant peptides derived from three myelin antigens: myelin binding protein, myelin oligodendrocyte glycoprotein and proteolipid protein. Autologous T-cell immunotherapy has been suggested to deplete or regulate the pathogenic myelin-reactive $T$ cells that maintain autoimmune processes within the CNS of patients with MS. The treatment procedure includes a collection of blood from the patient with MS and expansion of myelin-reactive $\mathrm{T}$ cells from the blood. Myelin-reactive T cells are formulated and attenuated by irradiation before returning the final product to the clinical site for subcutaneous administration to patients. A phase IIb placebo-controlled study was conducted in 150 subjects with RRMS and CIS. Although safe, Tcelna ${ }^{\mathrm{TM}}$ showed no statistically significant clinical or radiological benefit [190]. A phase II randomised trial, Abili-T, was performed and concluded in 183 patients with SPMS, but the publication of the results is pending.

\section{Future Strategies for Secondary Progressive MS Therapeutics}

Disability progression in MS is a continuous and slow process that can take years. Similarly, new drug discovery and testing can take up to 15 years with success not guaranteed. To expedite the finding of new treatments for SPMS, several methods have been proposed [24, 25, 64]. Population characteristics and outcome measures should be carefully chosen and be consistent with the main objectives that motivated the research. Innovative trial design or repurposing drugs are two ways to increase efficiency and cut costs of drug discovery. Finally, drug efficacy can be increased by combining drugs with different mechanisms of action.

\subsection{New Trial Designs}

Large-scale, long-term, placebo-controlled parallel-group trials, using a 1:1 ratio, have been used so far to assess efficacy drug in progressive MS. The efficiency of clinical trials in SPMS can potentially be increased by allowing a number of treatments to be tried concurrently. Adaptive seamless designs are feasible in SPMS [140, 142]. Multi-stage or multi-arm randomised trials have been successfully used in other medical research areas, such as oncology for some time [191]. In 1999, for example, Bauer and Kieser proposed an adaptive two-stage design for the situation of multiple treatments to be compared with a control within a single confirmatory trial [192]. Such a trial would allow for an interim analysis to determine early termination or continuation of the study towards a second stage. Adaptive design methods are also useful in the early phases of drug development as they are dynamically informative [193, 194].

\subsection{Drug Repurposing}

Drug repurposing, also known as drug repositioning or drug re-profiling, is the application of already approved drugs to new diseases [195, 196]. It is advantageous because the repurposed drugs have already passed the trial stages assessing safety in humans, reducing the time and costs of drug development [197-200].

In the past, drug repositioning was merely a consequence of chance or unforeseen drug effects, whereas today computational methods have been developed to predict new targets for established drug or different drugs that act on the same target [196, 197, 201]. Structurally similar molecules can predict similar biological effects [202-204]. Molecular activities of drugs can be also inferred based on their side effects, or predicted from the human genome [198, 205]. 
Faissner and colleagues looked for repurposed drugs with neuroprotective potential targeting iron deposition in the CNS, which is thought to mediate mitochondrial dysfunction neurotoxicity in progressive MS. They showed that tricyclic antidepressants, antipsychotics and indapamide might work in progressive MS. They also showed that clomipramine was able to suppress or improve EAE [206].

Vesterinen and colleagues developed an evidence-based framework to select oral repurposed neuroprotective drugs to be tested in SPMS [207]. They found at least seven agents with putative neuroprotective properties. Three of these agents are under investigation in the MS-SMART trial and one has been successful in the SPRINT-MS study [142, 208].

\subsection{Combination Therapy}

Combination therapy is widely used in medicine, including in the treatment of immune disorders, such as rheumatoid arthritis. The rationale for the use of combination therapy in MS, as highlighted by Conway and Cohen, is supported by the different mechanisms of action of the various available DMTs that can also have additive or synergistic efficacy [209]. Combination therapy has advantages and disadvantages, and drugs with different mechanisms of action can target different aspects of the disease pathogenesis, which is complex and heterogeneous, but can also have additive side effects [210]. Some attempts at combination therapy have been undertaken, but no convincing results have been found [211-214].

Consistent with the rationale of combining immunomodulators with distinct mechanism of action, other combinations have obtained additive or synergistic effects in preclinical studies, showing a positive effect of combining vitamin $\mathrm{D}$ and interferon- $\beta$. The combination of anti-inflammatory and neuroprotective agents has also been tried in small studies such as the phase II trial combining intramuscular interferon- $\beta$-1a with riluzole or the trials combining minocycline and interferon- $\beta$ or glatiramer acetate in RRMS $[135,151,209]$. The CombiRx trial, combining interferon$\beta$-1a and glatiramer acetate, enrolled more than a thousand patients with RRMS. Although the combination therapy did not produce a significant clinical benefit, there was evidence of superiority of the combination therapy over single-arm treatment in reducing new lesion activity and accumulation of total lesion volumes [211].

\section{Conclusions}

Studies in progressive MS have been increasing over the past two decades and there are many investigational products currently in the pipeline for both SPMS and PPMS (Tables 1,
2, 3, 4, 5). With the ORATORIO trial, ocrelizumab represents the first drug that has shown some evidence of efficacy in PPMS. More recently, the EXPAND trial has provided evidence of the efficacy of siponimod in SPMS [215, 216]. Ocrelizumab and siponimod reduced the worsening of disability over time in PPMS and SPMS, respectively, but whether this effect is directly owing to an interference with neurodegeneration or mediated by an anti-inflammatory effect is still debated [217]. New evidence from immunology and pathology is changing our understanding of MS, which is no longer felt as a two-stage disease but rather a continuum, where both inflammation and neurodegeneration are contemporarily present at any moment in the course of the disease [16, 218]. The EXPAND and ORATORIO trials suggest a greater therapeutic effect in patients with relative short disease duration, younger age and signs of baseline activity.

As we have written in this review, treatments in progressive MS will probably include an anti-inflammatory approach, which is likely to be combined with myelin repair and neuroprotection. The use of repurposed drugs and combination therapy looks promising. Targeting specific study populations with appropriate outcome measures and efficient trial designs is essential to speed up the discovery of new pharmacotherapies for SPMS [24-27].

Author contributions FDeA and JC were both involved in the conception and design of the article, and the drafting, revision and final approval of the manuscript for publication. DP contributed to the revision of the manuscript.

\section{Compliance with Ethical Standards}

Funding No funding was received for the preparation of this article.

Conflict of interest Floriana De Angelis and Domenico Plantone have no conflicts of interest directly relevant to the content of this article. Jeremy Chataway has received support from the Efficacy and Mechanism Evaluation Programme and Health Technology Assessment Programme (National Institute for Health Research), UK Multiple Sclerosis Society and National Multiple Sclerosis Society. In the last 3 years, he has been a local principal investigator for trials in multiple sclerosis funded by Receptos, Novartis and Biogen Idec, and has received an investigator grant from Novartis outside this work. He has taken part in advisory boards/consultancies for Roche, Merck, MedDay, Biogen and Apitope.

\section{References}

1. Thompson AJ, Banwell BL, Barkhof F, Carroll WM, Coetzee T, Comi G, et al. Diagnosis of multiple sclerosis: 2017 revisions of the McDonald criteria. Lancet Neurol. 2018;17(2):162-73. https ://doi.org/10.1016/s1474-4422(17)30470-22017.

2. Lublin FD, Reingold SC, Cohen JA, Cutter GR, Sørensen PS, Thompson AJ, et al. Defining the clinical course of multiple 
sclerosis: the 2013 revisions. Neurology. 2014;83:278-86. https ://doi.org/10.1212/WNL.0000000000000560.

3. Miller DH, Chard DT, Ciccarelli O. Clinically isolated syndromes. Lancet Neurol. 2012;11:157-69. https://doi.org/10.1016/ S1474-4422(11)70274-5.

4. Granberg T, Martola J, Kristoffersen-Wiberg M, Aspelin P, Fredrikson S. Radiologically isolated syndrome: incidental magnetic resonance imaging findings suggestive of multiple sclerosis, a systematic review. Mult Scler. 2013;19:271-80. https://doi. org/10.1177/1352458512451943.

5. Kawachi I, Lassmann H. Neurodegeneration in multiple sclerosis and neuromyelitis optica. J Neurol Neurosurg Psychiatry. 2017;88(2):137-45. https://doi.org/10.1136/jnnp-2016-313300.

6. Kutzelnigg A, Lucchinetti CF, Stadelmann C, Brück W, Rauschka $\mathrm{H}$, Bergmann M, et al. Cortical demyelination and diffuse white matter injury in multiple sclerosis. Brain. 2005;128:2705-12. https://doi.org/10.1093/brain/awh641.

7. Mandolesi G, Gentile A, Musella A, Fresegna D, De Vito F, Bullitta S, et al. Synaptopathy connects inflammation and neurodegeneration in multiple sclerosis. Nat Rev Neurol. 2015;11(12):711-24. https://doi.org/10.1038/nrneurol.2015.222.

8. Compston A, Coles A. Multiple sclerosis. Lancet. 2008;372:1502-17. https://doi.org/10.1016/S0140 $-6736(08) 61620-7$.

9. Trapp BD, Nave K-A. Multiple sclerosis: an immune or neurodegenerative disorder? Annu Rev Neurosci. 2008;31:247-69. https ://doi.org/10.1146/annurev.neuro.30.051606.094313.

10. Hauser SL, Chan JR, Oksenberg JR. Multiple sclerosis: prospects and promise. Ann Neurol. 2013;74:317-27. https://doi. org/10.1002/ana.24009.

11. Kapoor R. Neuroprotection in multiple sclerosis: therapeutic strategies and clinical trial design. Curr Opin Neurol. 2006;19:255-9. https://doi.org/10.1097/01.wco.0000227034 .85576 .16 .

12. Sawcer S, Hellenthal G, Pirinen M, Spencer CC, Patsopoulos NA, Moutsianas L, et al. Genetic risk and a primary role for cell-mediated immune mechanisms in multiple sclerosis. Nature. 2011;476:214-9. https://doi.org/10.1038/nature10251.

13. Hemmer B, Kerschensteiner M, Korn T. Role of the innate and adaptive immune responses in the course of multiple sclerosis. Lancet Neurol. 2015;14:406-19. https://doi.org/10.1016/S1474 $-4422(14) 70305-9$.

14. Ciccarelli O, Barkhof F, Bodini B, De Stefano N, Golay X, Nicolay K, et al. Pathogenesis of multiple sclerosis: insights from molecular and metabolic imaging. Lancet Neurol. 2014;13:80722. https://doi.org/10.1016/S1474-4422(14)70101-2.

15. Christensen JR, Börnsen L, Ratzer R, Piehl F, Khademi M, Olsson $\mathrm{T}$, et al. Systemic inflammation in progressive multiple sclerosis involves follicular T-helper, Th17- and activated B-cells and correlates with progression. PLoS One. 2013;8:e57820. https:// doi.org/10.1371/journal.pone.0057820.

16. Lassmann H. Targets of therapy in progressive MS. Mult Scler. 2017;23:1593-9. https://doi.org/10.1177/1352458517729455.

17. Yates RL, Esiri MM, Palace J, Jacobs B, Perera R, DeLuca GC. Fibrin(ogen) and neurodegeneration in the progressive multiple sclerosis cortex. Ann Neurol. 2017;82:259-70. https://doi. org/10.1002/ana.24997.

18. Fisher E, Lee J-C, Nakamura K, Rudick RA. Gray matter atrophy in multiple sclerosis: a longitudinal study. Ann Neurol. 2008;64:255-65. https://doi.org/10.1002/ana.21436.

19. Fisniku LK, Chard DT, Jackson JS, Anderson VM, Altmann DR, Miszkiel KA, et al. Gray matter atrophy is related to long-term disability in multiple sclerosis. Ann Neurol. 2008;64:247-54. https://doi.org/10.1002/ana.21423.

20. Magliozzi R, Howell O, Vora A, Serafini B, Nicholas R, Puopolo M, et al. Meningeal B-cell follicles in secondary progressive multiple sclerosis associate with early onset of disease and severe cortical pathology. Brain. 2007;130(Pt 4):1089-104. https://doi.org/10.1093/brain/awm038.

21. Howell OW, Reeves CA, Nicholas R, Carassiti D, Radotra B, Gentleman SM, et al. Meningeal inflammation is widespread and linked to cortical pathology in multiple sclerosis. Brain. 2011;134:2755-71. https://doi.org/10.1093/brain/awr182.

22. Lisak RP, Benjamins JA, Nedelkoska L, Barger JL, Ragheb $\mathrm{S}$, Fan B, et al. Secretory products of multiple sclerosis B cells are cytotoxic to oligodendroglia in vitro. J Neuroimmunol. 2012;246:85-95. https://doi.org/10.1016/j.jneur oim.2012.02.015.

23. Lisak RP, Nedelkoska L, Benjamins JA, Schalk D, Bealmear B, Touil H, et al. B cells from patients with multiple sclerosis induce cell death via apoptosis in neurons in vitro. J Neuroimmunol. 2017;309:88-99. https://doi.org/10.1016/j.jneur oim.2017.05.004.

24. Ontaneda D, Fox RJ, Chataway J. Clinical trials in progressive multiple sclerosis: lessons learned and future perspectives. Lancet Neurol. 2015;14:208-23. https://doi.org/10.1016/S1474 -4422(14)70264-9.

25. Plantone D, De Angelis F, Doshi A, Chataway J. Secondary progressive multiple sclerosis: definition and measurement. CNS Drugs. 2016;30:517-26. https://doi.org/10.1007/s4026 3-016-0340-9.

26. Ontaneda D. Inadequate outcome measures are the biggest impediment to successful clinical trials in progressive MS: commentary. Mult Scler. 2017;23:508-9. https://doi. org/10.1177/1352458516674368.

27. van Munster CEP, Uitdehaag BMJ. Outcome measures in clinical trials for multiple sclerosis. CNS Drugs. 2017;31:217-36. https ://doi.org/10.1007/s40263-017-0412-5.

28. Kalincik T, Cutter G, Spelman T, Jokubaitis V, Havrdova E, Horakova $\mathrm{D}$, et al. Defining reliable disability outcomes in multiple sclerosis. Brain. 2015;138:3287-98. https://doi.org/10.1093/ brain/awv258.

29. Kurtzke JF. Rating neurologic impairment in multiple sclerosis: an Expanded Disability Status Scale (EDSS). Neurology. 1983;33:1444-52.

30. Cutter GR, Baier ML, Rudick RA, Cookfair DL, Fischer JS, Petkau J, et al. Development of a multiple sclerosis functional composite as a clinical trial outcome measure. Brain. 1999;122:87182. https://doi.org/10.1093/brain/122.5.871.

31. Fischer JS, Rudick RA, Cutter GR, Reingold SC. The multiple sclerosis functional composite measure (MSFC): an integrated approach to MS clinical outcome assessment. National MS Society Clinical Outcomes Assessment Task Force. Mult Scler. 1999;5:244-50.

32. Amato MP, Ponziani G. Quantification of impairment in MS: discussion of the scales in use. Mult Scler. 1999;5:216-9. https ://doi.org/10.1177/135245859900500404.

33. Benedict RH, DeLuca J, Phillips G, LaRocca N, Hudson LD, Rudick R, et al. Validity of the symbol digit modalities test as a cognition performance outcome measure for multiple sclerosis. Mult Scler. 2017;23:721-33. https://doi.org/10.1177/13524 58517690821.

34. Brochet B, Deloire MSA, Bonnet M, Salort-Campana E, Ouallet JC, Petry KG, et al. Should SDMT substitute for PASAT in MSFC? A 5-year longitudinal study. Mult Scler. 2008;14:12429. https://doi.org/10.1177/1352458508094398.

35. Balcer LJ, Baier ML, Cohen JA, Kooijmans MF, Sandrock AW, Nano-Schiavi ML, et al. Contrast letter acuity as a visual component for the multiple sclerosis functional composite. Neurology. 2003;61:1367-73.

36. Balcer LJ, Raynowska J, Nolan R, Galetta SL, Kapoor R, Benedict $\mathrm{R}$, et al. Validity of low-contrast letter acuity as a visual 
performance outcome measure for multiple sclerosis. Mult Scler. 2017;23:734-47. https://doi.org/10.1177/1352458517690822.

37. Tur C, Moccia M, Barkhof F, Chataway J, Sastre-Garriga J, Thompson AJ, et al. Assessing treatment outcomes in multiple sclerosis trials and in the clinical setting. Nat Rev Neurol. 2018;14:75-93. https://doi.org/10.1038/nrneurol.2017.171.

38. Moccia M, de Stefano N, Barkhof F. Imaging outcome measures for progressive multiple sclerosis trials. Mult Scler. 2017;23:1614-26. https://doi.org/10.1177/1352458517729456.

39. Kearney H, Miller DH, Ciccarelli O. Spinal cord MRI in multiple sclerosis: diagnostic, prognostic and clinical value. Nat Rev Neurol. 2015;11:327-38. https://doi.org/10.1038/nrneurol.2015.80.

40. Miller DH, Barkhof F, Frank JA, Parker GJM, Thompson AJ. Measurement of atrophy in multiple sclerosis: pathological basis, methodological aspects and clinical relevance. Brain. 2002;125:1676-95.

41. Losseff NA, Wang L, Lai HM, Yoo DS, Gawne-Cain ML, McDonald WI, et al. Progressive cerebral atrophy in multiple sclerosis: a serial MRI study. Brain. 1996;119(Pt 6):2009-19.

42. Kalkers NF, Bergers E, Castelijns JA, van Walderveen MA, Bot $\mathrm{JC}$, Adèr HJ, et al. Optimizing the association between disability and biological markers in MS. Neurology. 2001;57:1253-8.

43. De Stefano N, Giorgio A, Battaglini M, Rovaris M, Sormani MP, Barkhof F, et al. Assessing brain atrophy rates in a large population of untreated multiple sclerosis subtypes. Neurology. 2010;74:1868-76. https://doi.org/10.1212/WNL.0b013e3181 e24136.

44. Bermel RA, Bakshi R. The measurement and clinical relevance of brain atrophy in multiple sclerosis. Lancet Neurol. 2006;5:158-70. https://doi.org/10.1016/S1474-4422(06)70349 -0 .

45. Calabresi PA, Balcer LJ, Frohman EM, editors. Optical Coherence Tomography in Neurologic Diseases. New York: Cambridge University Press; 2015. https://doi.org/10.1017/CBO97 81139649506.

46. Balcer LJ. Clinical trials to clinical use. J Neuroophthalmol. 2014;34:S18-23. https://doi.org/10.1097/wno.000000000000016 3.

47. Fisher J, Jacobs D, Markowitz C, Galetta S, Volpe N, Nanoschiabi M, et al. Relation of visual function to retinal nerve fiber layer thickness in multiple sclerosis. Ophthalmology. 2006;113:32432. https://doi.org/10.1016/j.ophtha.2005.10.040.

48. Coric D, Balk LJ, Uitdehaag BMJ, Petzold A. Diagnostic accuracy of optical coherence tomography inter-eye percentage difference for optic neuritis in multiple sclerosis. Eur J Neurol. 2017;24(12):1479-84. https://doi.org/10.1111/ene.13443.

49. Toledo J, Sepulcre J, Salinas-Alaman A, García-Layana A, Murie-Fernandez M, Bejarano B, et al. Retinal nerve fiber layer atrophy is associated with physical and cognitive disability in multiple sclerosis. Mult Scler. 2008;14:906-12. https://doi. org/10.1177/1352458508090221.

50. Balcer LJ, Miller DH, Reingold SC, Cohen JA. Vision and vision-related outcome measures in multiple sclerosis. Brain. 2015;138:11-27. https://doi.org/10.1093/brain/awu335.

51. Saidha S, Al-Louzi O, Ratchford JN, Bhargava P, Oh J, Newsome $\mathrm{SD}$, et al. Optical coherence tomography reflects brain atrophy in multiple sclerosis: a four-year study. Ann Neurol. 2015;78:80113. https://doi.org/10.1002/ana.24487.

52. Martinez-Lapiscina EH, Arnow S, Wilson JA, Saidha S, Preiningerova JL, Oberwahrenbrock T, et al. Retinal thickness measured with optical coherence tomography and risk of disability worsening in multiple sclerosis: a cohort study. Lancet Neurol. 2016;15:574-84. https://doi.org/10.1016/S1474-4422(16)00068 -5 .

53. Agah E, Zardoui A, Saghazadeh A, Ahmadi M, Tafakhori A, Rezaei N. Osteopontin (OPN) as a CSF and blood biomarker for multiple sclerosis: a systematic review and meta-analysis. PLoS One. 2018;13:e0190252. https://doi.org/10.1371/journ al.pone.0190252.

54. Zetterberg H. Fluid biomarkers for microglial activation and axonal injury in multiple sclerosis. Acta Neurol Scand. 2017;136:15-7. https://doi.org/10.1111/ane.12845.

55. Farez MF, Correale J. Sphingosine 1-phosphate signaling in astrocytes: implications for progressive multiple sclerosis. J Neurol Sci. 2016;361:60-5. https://doi.org/10.1016/j. jns.2015.12.022.

56. Hartung H-P, Gonsette R, Konig N, Kwiecinski H, Guseo A, Morrissey SP, et al. Mitoxantrone in progressive multiple sclerosis: a placebo-controlled, double-blind, randomised, multicentre trial. Lancet. 2002;360:2018-25. https://doi. org/10.1016/S0140-6736(02)12023-X.

57. Cross AH, Naismith RT. Established and novel diseasemodifying treatments in multiple sclerosis. J Intern Med. 2014;275:350-63. https://doi.org/10.1111/joim.12203.

58. Martinelli V, Cocco E, Capra R, Salemi G, Gallo P, Capobianco M, et al. Acute myeloid leukemia in Italian patients with multiple sclerosis treated with mitoxantrone. Neurology. 2011;77:1887-95. https://doi.org/10.1212/WNL.0b013e3182 $38 \mathrm{ee} 00$.

59. Le Page E, Leray E, Edan G, French Mitoxantrone Safety Group. Long-term safety profile of mitoxantrone in a French cohort of 802 multiple sclerosis patients: a 5-year prospective study. Mult Scler. 2011;17:867-75. https://doi.org/10.1177/1352458511 398371.

60. Edan G, Comi G, Le Page E, Leray E, Rocca MA, Filippi M, et al. Mitoxantrone prior to interferon beta- $1 \mathrm{~b}$ in aggressive relapsing multiple sclerosis: a 3-year randomised trial. J Neurol Neurosurg Psychiatry. 2011;82:1344-50. https://doi.org/10.1136/ jnnp.2010.229724.

61. Edan G, Le Page E. Induction therapy for patients with multiple sclerosis: Why? When? How? CNS Drugs. 2013;27:403-9. https ://doi.org/10.1007/s40263-013-0065-y.

62. Ontaneda D, Thompson AJ, Fox RJ, Cohen JA. Progressive multiple sclerosis: prospects for disease therapy, repair, and restoration of function. Lancet. 2017;389(10076):1357-66. https://doi. org/10.1016/S0140-6736(16)31320-4.

63. Shirani A, Okuda DT, Stüve O. Therapeutic advances and future prospects in progressive forms of multiple sclerosis. Neurotherapeutics. 2016;13:58-69. https://doi.org/10.1007/s1331 1-015-0409-z.

64. Nandoskar A, Raffel J, Scalfari AS, Friede T, Nicholas RS. Pharmacological approaches to the management of secondary progressive multiple sclerosis. Drugs. 2017;77:885-910. https ://doi.org/10.1007/s40265-017-0726-0.

65. Coles AJ. Alemtuzumab therapy for multiple sclerosis. Neurotherapeutics. 2013;10:29-33. https://doi.org/10.1007/s1331 1-012-0159-0.

66. Brown JWL, Coles AJ. Alemtuzumab: evidence for its potential in relapsing-remitting multiple sclerosis. Drug Des Dev Ther. 2013;7:131-8. https://doi.org/10.2147/DDDT.S32687.

67. Cohen JA, Coles AJ, Arnold DL, Confavreux C, Fox EJ, Hartung $\mathrm{H}-\mathrm{P}$, et al. Alemtuzumab versus interferon beta 1a as first-line treatment for patients with relapsing-remitting multiple sclerosis: a randomised controlled phase 3 trial. Lancet. 2012;380:181928. https://doi.org/10.1016/S0140-6736(12)61769-3.

68. Coles AJ, Twyman CL, Arnold DL, Cohen JA, Confavreux C, Fox EJ, et al. Alemtuzumab for patients with relapsing multiple sclerosis after disease-modifying therapy: a randomised controlled phase 3 trial. Lancet. 2012;380:1829-39. https://doi. org/10.1016/S0140-6736(12)61768-1.

69. Giovannoni G, Comi G, Cook S, Rammohan K, Rieckmann P, Sørensen PS, et al. A placebo-controlled trial of oral cladribine 
for relapsing multiple sclerosis. N Engl J Med. 2010;362:41626. https://doi.org/10.1056/NEJMoa0902533.

70. Leist TP, Comi G, Cree BAC, Coyle PK, Freedman MS, Hartung H-P, et al. Effect of oral cladribine on time to conversion to clinically definite multiple sclerosis in patients with a first demyelinating event (ORACLE MS): a phase 3 randomised trial. Lancet Neurol. 2014;13:257-67. https://doi.org/10.1016/ S1474-4422(14)70005-5.

71. Sipe JC, Romine JS, Koziol JA, McMillan R, Zyroff J, Beutler E. Cladribine in treatment of chronic progressive multiple sclerosis. Lancet. 1994;344:9-13.

72. Rice GP, Filippi M, Comi G. Cladribine and progressive MS: clinical and MRI outcomes of a multicenter controlled trial. Cladribine MRI Study Group. Neurology. 2000;54:1145-55. https://doi.org/10.1212/WNL.54.5.1145.

73. Filippi M, Rovaris M, Iannucci G, Mennea S, Sormani MP, Comi G. Whole brain volume changes in patients with progressive MS treated with cladribine. Neurology. 2000;55:1714-8.

74. Warren KG, Catz I, Ferenczi LZ, Krantz MJ. Intravenous synthetic peptide MBP8298 delayed disease progression in an HLA class II-defined cohort of patients with progressive multiple sclerosis: results of a 24-month double-blind placebo-controlled clinical trial and 5 years of follow-up treatment. Eur J Neurol. 2006;13:887-95. https://doi.org/10.111 1/j.1468-1331.2006.01533.x.

75. Freedman MS, Bar-Or A, Oger J, Traboulsee A, Patry D, Young C, et al. A phase III study evaluating the efficacy and safety of MBP8298 in secondary progressive MS. Neurology. 2011;77:1551-60. https://doi.org/10.1212/WNL.0b013e3182 $33 b 240$.

76. Colombo E, Di Dario M, Capitolo E, Chaabane L, Newcombe J, Martino G, et al. Fingolimod may support neuroprotection via blockade of astrocyte nitric oxide. Ann Neurol. 2014;76:325-37. https://doi.org/10.1002/ana.24217.

77. Barkhof F, de Jong R, Sfikas N, de Vera A, Francis G, Cohen $\mathrm{J}$. The influence of patient demographics, disease characteristics and treatment on brain volume loss in Trial Assessing Injectable Interferon vs FTY720 Oral in Relapsing-Remitting Multiple Sclerosis (TRANSFORMS), a phase 3 study of fingolimod. Mult Scler. 2014;20(13):1704-13. https://doi. org/10.1177/1352458514532317.

78. Lublin F, Miller DH, Freedman MS, Cree BAC, Wolinsky JS, Weiner $\mathrm{H}$, et al. Oral fingolimod in primary progressive multiple sclerosis (INFORMS): a phase 3, randomised, doubleblind, placebo-controlled trial. Lancet. 2016;387:1075-84. https://doi.org/10.1016/S0140-6736(15)01314-8.

79. White M, Webster G, O'Sullivan D, Stone S, La Flamme AC. Targeting innate receptors with MIS416 reshapes Th responses and suppresses CNS disease in a mouse model of multiple sclerosis. PLoS One. 2014;9:e87712. https://doi.org/10.1371/ journal.pone.0087712.

80. Luckey AM, Anderson T, Silverman MH, Webster G. Safety, tolerability and pharmacodynamics of a novel immunomodulator, MIS416, in patients with chronic progressive multiple sclerosis. Mult Scler J Exp Transl Clin. 2015;1:2055217315583385. https://doi.org/10.1177/20552 17315583385 .

81. National Multiple Sclerosis Society. Results announced from phase 2 trial of MIS416 in secondary progressive MS suggest no benefit n.d. https://www.nationalmssociety.org/About-the-Socie ty/News/Results-Announced-from-Phase-2-Trial-of-MIS416-in. Accessed 26 Feb 2018.

82. Lycke J. Monoclonal antibody therapies for the treatment of relapsing-remitting multiple sclerosis: differentiating mechanisms and clinical outcomes. Ther Adv Neurol Disord. 2015;8:274-93. https://doi.org/10.1177/1756285615605429.
83. McGinley MP, Moss BP, Cohen JA. Safety of monoclonal antibodies for the treatment of multiple sclerosis. Expert Opin Drug Saf. 2017;16(1):89-100. https://doi.org/10.1080/14740 338.2017.1250881.

84. Gan Y, Liu R, Wu W, Bomprezzi R, Shi F-D. Antibody to $\alpha 4$ integrin suppresses natural killer cells infiltration in central nervous system in experimental autoimmune encephalomyelitis. J Neuroimmunol. 2012;247:9-15. https://doi.org/10.1016/j.jneur oim.2012.03.011.

85. Romme Christensen J, Ratzer R, Bornsen L, Lyksborg M, Garde E, Dyrby TB, et al. Natalizumab in progressive MS: results of an open-label, phase 2A, proof-of-concept trial. Neurology. 2014;82:1499-507. https://doi.org/10.1212/WNL.0000000000 000361.

86. Kapoor R, Ho P-R, Campbell N, Chang I, Deykin A, Forrestal $F$, et al. Effect of natalizumab on disease progression in secondary progressive multiple sclerosis (ASCEND): a phase 3, randomised, double-blind, placebo-controlled trial with an openlabel extension. Lancet Neurol. 2018;17(5):405-15. https://doi. org/10.1016/S1474-4422(18)30069-3.

87. Noseworthy JH, O'Brien P, Erickson BJ, Lee D, Sneve D, Ebers GC, et al. The Mayo Clinic-Canadian Cooperative trial of sulfasalazine in active multiple sclerosis. Neurology. 1998;51:1342-52.

88. Kim S, Lee Y-I, Chang K-Y, Lee D-W, Cho SC, Ha YW, et al. Promotion of remyelination by sulfasalazine in a transgenic zebrafish model of demyelination. Mol Cells. 2015;38:1013-21. https://doi.org/10.14348/molcells.2015.0246.

89. Hauser S, Waubant E, Arnold DL, Vollmer T, Antel J, Fox RJ, et al. B-cell depletion with rituximab in relapsing-remitting multiple sclerosis. N Engl J Med. 2008;358:676-88. https://doi. org/10.1017/CBO9781107415324.004.

90. Hawker K, O'Connor P, Freedman MS, Calabresi PA, Antel J, Simon J, et al. Rituximab in patients with primary progressive multiple sclerosis: results of a randomized double-blind placebocontrolled multicenter trial. Ann Neurol. 2009;66:460-71. https ://doi.org/10.1002/ana.21867.

91. Komori M, Lin YC, Cortese I, Blake A, Ohayon J, Cherup J, et al. Insufficient disease inhibition by intrathecal rituximab in progressive multiple sclerosis. Ann Clin Transl Neurol. 2016;3(3):166-79. https://doi.org/10.1002/acn3.293.

92. Hauser SL, Bar-Or A, Comi G, Giovannoni G, Hartung H-P, Hemmer B, et al. Ocrelizumab versus interferon beta-1a in relapsing multiple sclerosis. N Engl J Med. 2017;376:221-34. https://doi.org/10.1056/NEJMoa1601277.

93. Selmaj K, Li DK, Hartung H-P, Hemmer B, Kappos L, Freedman MS, et al. Siponimod for patients with relapsing-remitting multiple sclerosis (BOLD): an adaptive, dose-ranging, randomised, phase 2 study. Lancet Neurol. 2013;12:756-67. https://doi. org/10.1016/S1474-4422(13)70102-9.

94. Kappos L, Li DKB, Stüve O, Hartung H-P, Freedman MS, Hemmer B, et al. Safety and efficacy of siponimod (BAF312) in patients with relapsing-remitting multiple sclerosis. JAMA Neurol. 2016;73:1089. https://doi.org/10.1001/jamaneurol .2016.1451.

95. Kappos L, Bar-Or A, Cree BAC, Fox RJ, Giovannoni G, Gold $\mathrm{R}$, et al. Siponimod versus placebo in secondary progressive multiple sclerosis (EXPAND): a double-blind, randomised, phase 3 study. Lancet. 2018;391(10127):1263-73. https://doi. org/10.1016/S0140-6736(18)30475-6.

96. Metz LM, Liu W-Q. Effective treatment of progressive MS remains elusive. Lancet. 2018;391:1239-40. https://doi. org/10.1016/S0140-6736(18)30426-4.

97. Muraro PA, Pasquini M, Atkins HL, Bowen JD, Farge D, Fassas A, et al. Long-term outcomes after autologous hematopoietic stem cell transplantation for multiple sclerosis. JAMA 
Neurol. 2017;74(4):459-69. https://doi.org/10.1001/jamaneurol 2016.5867

98. Sormani MP, Muraro PA, Schiavetti I, Signori A, Laroni A, Saccardi R, et al. Autologous hematopoietic stem cell transplantation in multiple sclerosis. Neurology. 2017;88:2115-22. https://doi. org/10.1212/WNL.0000000000003987.

99. Linker RA, Lee D-H, Ryan S, van Dam AM, Conrad R, Bista $\mathrm{P}$, et al. Fumaric acid esters exert neuroprotective effects in neuroinflammation via activation of the Nrf2 antioxidant pathway. Brain. 2011;134:678-92. https://doi.org/10.1093/brain/awq386.

100. Plantone D, De Angelis F, Doshi A, Chataway J. Dimethyl fumarate may still have a role in progressive multiple sclerosis. Ther Adv Neurol Disord. 2016;9:344-5. https://doi.org/10.1177/17562 85616640396.

101. Strassburger-Krogias K, Ellrichmann G, Krogias C, Altmeyer P, Chan A, Gold R. Fumarate treatment in progressive forms of multiple sclerosis: first results of a single-center observational study. Ther Adv Neurol Disord. 2014;7:232-8. https://doi. org/10.1177/1756285614544466.

102. Theoharides TC, Cochrane DE. Critical role of mast cells in inflammatory diseases and the effect of acute stress. J Neuroimmunol. 2004;146:1-12.

103. Dubreuil P, Letard S, Ciufolini M, Gros L, Humbert M, Castéran $\mathrm{N}$, et al. Masitinib (AB1010), a potent and selective tyrosine kinase inhibitor targeting KIT. PLoS One. 2009;4:e7258. https ://doi.org/10.1371/journal.pone.0007258.

104. AB Science FC\& MR. AB Science announces that masitinib study in primary and secondary progressive forms of multiple sclerosis has passed its non-futility test at 2 years. 2017. http:// www.ab-science.com. Accessed 17 Apr 2017.

105. Vermersch P, Benrabah R, Schmidt N, Zéphir H, Clavelou P, Vongsouthi $C$, et al. Masitinib treatment in patients with progressive multiple sclerosis: a randomized pilot study. BMC Neurol. 2012;12:36. https://doi.org/10.1186/1471-2377-12-36.

106. Haider L, Zrzavy T, Hametner S, Höftberger R, Bagnato F, Grabner $\mathrm{G}$, et al. The topograpy of demyelination and neurodegeneration in the multiple sclerosis brain. Brain. 2016;139:807-15. https://doi.org/10.1093/brain/awv398.

107. Gowran A, Noonan J, Campbell VA. The multiplicity of action of cannabinoids: implications for treating neurodegeneration. CNS Neurosci Ther. 2011;17:637-44. https://doi.org/10.111 1/j.1755-5949.2010.00195.x.

108. Zajicek J, Fox P, Sanders H, Wright D, Vickery J, Nunn A, et al. Cannabinoids for treatment of spasticity and other symptoms related to multiple sclerosis (CAMS study): multicentre randomised placebo-controlled trial. Lancet. 2003;362:1517-26. https://doi.org/10.1016/S0140-6736(03)14738-1.

109. Zajicek J, Ball S, Wright D, Vickery J, Nunn A, Miller D, et al. Effect of dronabinol on progression in progressive multiple sclerosis (CUPID): a randomised, placebo-controlled trial. Lancet Neurol. 2013;12:857-65. https://doi.org/10.1016/S1474 -4422(13)70159-5.

110. Bartels C, Späte K, Krampe H, Ehrenreich H. Recombinant human erythropoietin: novel strategies for neuroprotective/neuroregenerative treatment of multiple sclerosis. Ther Adv Neurol Disord. 2008;1:193-206. https://doi.org/10.1177/1756285608 098422.

111. Ehrenreich H, Fischer B, Norra C, Schellenberger F, Stender N, Stiefel M, et al. Exploring recombinant human erythropoietin in chronic progressive multiple sclerosis. Brain. 2007;130:2577-88. https://doi.org/10.1093/brain/awm203.

112. Schreiber K, Magyari M, Sellebjerg F, Iversen P, Garde E, Madsen CG, et al. High-dose erythropoietin in patients with progressive multiple sclerosis: a randomized, placebo-controlled, phase 2 trial. Mult Scler. 2017;23:675-85. https://doi. org/10.1177/1352458516661048.
113. Jaber S, Polster BM. Idebenone and neuroprotection: antioxidant, pro-oxidant, or electron carrier? J Bioenerg Biomembr. 2015;47:111-8. https://doi.org/10.1007/s10863-014-9571-y.

114. Santhera reports. Outcome of exploratory trial with idebenone in PPMS conducted at the NIH. http://www.santhera.com/ assets/files/press-releases/2018-03-05_PR_PPMS_e_final.pdf. Accessed 7 Mar 2018

115. Kapoor R, Furby J, Hayton T, Smith KJ, Altmann DR, Brenner $\mathrm{R}$, et al. Lamotrigine for neuroprotection in secondary progressive multiple sclerosis: a randomised, double-blind, placebocontrolled, parallel-group trial. Lancet Neurol. 2010;9:681-8. https://doi.org/10.1016/S1474-4422(10)70131-9.

116. Koudriavtseva T, Mainero C. Brain atrophy as a measure of neuroprotective drug effects in multiple sclerosis: influence of inflammation. Front Hum Neurosci. 2016;10:226. https://doi. org/10.3389/fnhum.2016.00226.

117. Mishra MK, Wang J, Keough MB, Fan Y, Silva C, Sloka S, et al. Laquinimod reduces neuroaxonal injury through inhibiting microglial activation. Ann Clin Transl Neurol. 2014;1:409-22. https://doi.org/10.1002/acn3.67.

118. Barkhof F, Giovannoni G, Hartung H-P, Cree B, Uccelli A, Sormani MP, et al. ARPEGGIO: a randomized, placebo-controlled study to evaluate oral laquinimod in patients with primary progressive multiple sclerosis (PPMS) (P7.210). Neurology. 2015;84(14 Supplement).

119. Active Biotech. Press releases: Active Biotech announce results in ARPEGGIO phase II trial with laquinimod in primary progressive MS. http://www.activebiotech.com/en/media/pressrelea ses/?id=2153402\&date $=1512129600$. Accessed 2 Apr 2018.

120. Chiu C-T, Chuang D-M. Neuroprotective action of lithium in disorders of the central nervous system. Zhong Nan Da Xue Xue Bao Yi Xue Ban. 2011;36:461-76. https://doi.org/10.3969/j. issn.1672-7347.2011.06.001.

121. Rinker JR, Meador W, Sung V, Nicholas A, Cutter G. Results of a pilot trial of lithium in progressive multiple sclerosis. ECTRIMS online library. 16 Sep 2016; 145965. http://onlinelibrary.ectri ms-congress.eu/ectrims/2016/32nd/145965/john.rinker.ii.resul ts.of.a.pilot.trial.of.lithium.in.progressive.multiple.html?f=m2. Accessed 19 Apr 2017.

122. Lovera J, Ramos A, Devier D, Garrison V, Kovner B, Reza T, et al. Polyphenon E, non-futile at neuroprotection in multiple sclerosis but unpredictably hepatotoxic: phase I single group and phase II randomized placebo-controlled studies. J Neurol Sci. 2015;358:46-52. https://doi.org/10.1016/j.jns.2015.08.006.

123. Rolan P, Hutchinson M, Johnson K. Ibudilast: a review of its pharmacology, efficacy and safety in respiratory and neurological disease. Expert Opin Pharmacother. 2009;10:2897-904. https:// doi.org/10.1517/14656560903426189.

124. Mizuno T, Kurotani T, Komatsu Y, Kawanokuchi J, Kato H, Mitsuma N, et al. Neuroprotective role of phosphodiesterase inhibitor ibudilast on neuronal cell death induced by activated microglia. Neuropharmacology. 2004;46:404-11. https://doi. org/10.1016/j.neuropharm.2003.09.009.

125. Barkhof F, Hulst HE, Drulovic J, Uitdehaag BMJ, Matsuda K, Landin R, et al. Ibudilast in relapsing-remitting multiple sclerosis: a neuroprotectant? Neurology. 2010;74:1033-40. https://doi. org/10.1212/WNL.0b013e3181d7d651.

126. Fox RJ, Coffey CS, Cudkowicz ME, Gleason T, Goodman A, Klawiter EC, et al. SPRINT-MS/NN 102 phase II trial of ibudilast in progressive MS. ECTRIMS-ACTRIMS meeting, 2017; Paris. ECTRIMS online library. https://onlinelibrary.ectrimscongress.eu/ectrims/2017/ACTRIMS-ECTRIMS2017/202642/ robert.j.fox.sprint-ms.nn.102.phase.ii.trial.of.ibudilast.in.progr essive.ms.html?f=media=3. Accessed 28 Oct 2017.

127. Naismith R, Coffey CS, Cudkowicz ME, Gleason T, Goodman AD, Klawiter EC, et al. Sprint-MS/NN 102 phase II trial 
of Ibudilast in progressive MS: top-line results. ACTRIMS forum, 2018; San Diego (CA). https://actrims.confex.com/actri ms/2018/meetingapp.cgi/Paper/2678. Accessed 3 Apr 2018.

128. Morini M, Roccatagliata L, Dell'Eva R, Pedemonte E, Furlan $\mathrm{R}$, Minghelli $\mathrm{S}$, et al. $\alpha$-Lipoic acid is effective in prevention and treatment of experimental autoimmune encephalomyelitis. J Neuroimmunol. 2004;148:146-53. https://doi.org/10.1016/j. jneuroim.2003.11.021.

129. Marracci GH, Jones RE, McKeon GP, Bourdette DN. Alpha lipoic acid inhibits $\mathrm{T}$ cell migration into the spinal cord and suppresses and treats experimental autoimmune encephalomyelitis. J Neuroimmunol. 2002;131:104-14.

130. Spain R, Powers K, Murchison C, Heriza E, Winges K, Yadav $\mathrm{V}$, et al. Lipoic acid in secondary progressive MS: a randomized controlled pilot trial. Neurol Neuroimmunol Neuroinflamm. 2017;4:e374. https://doi.org/10.1212/NXI.0000000000 000374

131. Chen X, Ma X, Jiang Y, Pi R, Liu Y, Ma L. The prospects of minocycline in multiple sclerosis. J Neuroimmunol. 2011;235:18. https://doi.org/10.1016/J.JNEUROIM.2011.04.006.

132. Friedlander RM, Chen M, Ona VO, Li M, Ferrante RJ, Fink $\mathrm{KB}$, et al. Minocycline inhibits caspase- 1 and caspase- 3 expression and delays mortality in a transgenic mouse model of Huntington disease. Nat Med. 2000;6:797-801. https://doi. org/10.1038/77528.

133. Maier K, Merkler D, Gerber J, Taheri N, Kuhnert AV, Williams SK, et al. Multiple neuroprotective mechanisms of minocycline in autoimmune CNS inflammation. Neurobiol Dis. 2007;25:51425. https://doi.org/10.1016/j.nbd.2006.10.022.

134. Metz LM, Zhang Y, Yeung M, Patry DG, Bell RB, Stoian CA, et al. Minocycline reduces gadolinium-enhancing magnetic resonance imaging lesions in multiple sclerosis. Ann Neurol. 2004;55:756. https://doi.org/10.1002/ana.20111.

135. Metz L, Li D, Traboulsee A, Myles M, Duquette P, Godin J, et al. Glatiramer acetate in combination with minocycline in patients with relapsing-remitting multiple sclerosis: results of a Canadian, multicenter, double-blind, placebo-controlled trial. Mult Scler. 2009;15:1183-94. https://doi.org/10.1177/1352458509106779.

136. Sørensen PS, Sellebjerg F, Lycke J, Färkkilä M, Créange A, Lund $\mathrm{CG}$, et al. Minocycline added to subcutaneous interferon $\beta$-1a in multiple sclerosis: randomized RECYCLINE study. Eur J Neurol. 2016;23:861-70. https://doi.org/10.1111/ene.12953.

137. Metz LM, Li DKB, Traboulsee AL, Duquette P, Eliasziw M, Cerchiaro G, et al. Trial of minocycline in a clinically isolated syndrome of multiple sclerosis. N Engl J Med. 2017;376:2122-33. https://doi.org/10.1056/NEJMoa1608889.

138. Lo AC, Saab CY, Black JA, Waxman SG. Phenytoin protects spinal cord axons and preserves axonal conduction and neurological function in a model of neuroinflammation in vivo. J Neurophysiol. 2003;90:3566-71. https://doi.org/10.1152/jn.00434.2003.

139. Raftopoulos R, Hickman SJ, Toosy A, Sharrack B, Mallik S, Paling D, et al. Phenytoin for neuroprotection in patients with acute optic neuritis: a randomised, placebo-controlled, phase 2 trial. Lancet Neurol. 2016;15:259-69. https://doi.org/10.1016/ S1474-4422(16)00004-1.

140. Chataway J, Schuerer N, Alsanousi A, Chan D, MacManus D, Hunter K, et al. Effect of high-dose simvastatin on brain atrophy and disability in secondary progressive multiple sclerosis (MS-STAT): a randomised, placebo-controlled, phase 2 trial. Lancet. 2014;383:2213-21. https://doi.org/10.1016/S0140 -6736(13)62242-4.

141. Chan D, Binks S, Nicholas JM, Frost C, Cardoso MJ, Ourselin $\mathrm{S}$, et al. Effect of high-dose simvastatin on cognitive, neuropsychiatric, and health-related quality-of-life measures in secondary progressive multiple sclerosis: secondary analyses from the MS-STAT randomised, placebo-controlled trial. Lancet Neurol.
2017;16:591-600. https://doi.org/10.1016/S1474-4422(17)30113 $-8$.

142. Connick P, Miller D, Pavitt S, Giovannoni G, Wheeler-Kingshott C, Weir C, Stallard N, Hawkins C, Sharrack B, Cranswick G, Chandran SCJ. MS-SMART trial design and recruitment status: a multi-arm phase IIB. ECTRIMS online library. 16 Sep 2016; 145886. https://onlinelibrary.ectrims-congress.eu/ectri ms/2016/32nd/145886/peter.connick.ms-smart.trial.design.and. recruitment.status.a.multi-arm.phase.html?f=media=3. Accessed 20 Feb 2018.

143. Vergo S, Craner MJ, Etzensperger R, Attfield K, Friese MA, Newcombe $J$, et al. Acid-sensing ion channel 1 is involved in both axonal injury and demyelination in multiple sclerosis and its animal model. Brain. 2011;134:571-84. https://doi.org/10.1093/ brain/awq337.

144. Arun T, Tomassini V, Sbardella E, de Ruiter MB, Matthews L, Leite MI, et al. Targeting ASIC1 in primary progressive multiple sclerosis: evidence of neuroprotection with amiloride. Brain. 2013;136:106-15. https://doi.org/10.1093/brain/aws325.

145. McKee JB, Cottriall CL, Elston J, Epps S, Evangelou N, Gerry $\mathrm{S}$, et al. Amiloride does not protect retinal nerve fibre layer thickness in optic neuritis in a phase 2 randomised controlled trial. Mult Scler. 2017. https://doi.org/10.1177/1352458517742979.

146. Kong EKC, Peng L, Chen Y, Yu ACH, Hertz L. Up-regulation of 5-HT2B receptor density and receptor-mediated glycogenolysis in mouse astrocytes by long-term fluoxetine administration. Neurochem Res. 2002;27:113-20.

147. Allaman I, Fiumelli H, Magistretti PJ, Martin J-L. Fluoxetine regulates the expression of neurotrophic/growth factors and glucose metabolism in astrocytes. Psychopharmacology (Berl). 2011;216:75-84. https://doi.org/10.1007/s00213-011-2190-y.

148. Mostert J, Heersema T, Mahajan M, Van Der Grond J, Van Buchem MA, De Keyser J. The effect of fluoxetine on progression in progressive multiple sclerosis: a double-blind, randomized, placebo-controlled trial. ISRN Neurol. 2013;2013:370943. https ://doi.org/10.1155/2013/370943.

149. Cambron M, Mostert J, Parra J, D'hooghe M, Nagels G, Willekens B, et al. Fluoxetine in progressive multiple sclerosis (FLUOX-PMS). ECTRIMS meeting 2016, London. ECTRIMS online library. http://onlinelibrary.ectrims-congress.eu/ectri ms/2016/32nd/147080/melissa.cambron.fluoxetine.in.progr essive.multiple.sclerosis.28fluox-pms29.html?f=m3. Accessed 22 July 2017.

150. Killestein J, Kalkers NF, Polman CH. Glutamate inhibition in MS: the neuroprotective properties of riluzole. J Neurol Sci. 2005;233:113-5. https://doi.org/10.1016/j.jns.2005.03.011.

151. Waubant E, Maghzi A-H, Revirajan N, Spain R, Julian L, Mowry $\mathrm{EM}$, et al. A randomized controlled phase II trial of riluzole in early multiple sclerosis. Ann Clin Transl Neurol. 2014;1:340-7. https://doi.org/10.1002/acn3.60.

152. Chen Y, Zhen W, Guo T, Zhao Y, Liu A, Rubio JP, et al. Histamine receptor 3 negatively regulates oligodendrocyte differentiation and remyelination. PLoS One. 2017;12:e0189380. https:// doi.org/10.1371/journal.pone.0189380.

153. Schwartzbach CJ, Grove RA, Brown R, Tompson D, Then Bergh F, Arnold DL. Lesion remyelinating activity of GSK239512 versus placebo in patients with relapsing-remitting multiple sclerosis: a randomised, single-blind, phase II study. J Neurol. 2017;264:304-15. https://doi.org/10.1007/s00415-016-8341-7.

154. Mi S, Hu B, Hahm K, Luo Y, Kam Hui ES, Yuan Q, et al. LINGO-1 antagonist promotes spinal cord remyelination and axonal integrity in MOG-induced experimental autoimmune encephalomyelitis. Nat Med. 2007;13:1228-33. https://doi. org/10.1038/nm1664.

155. Mi S, Miller RH, Tang W, Lee X, Hu B, Wu W, et al. Promotion of central nervous system remyelination by induced 
differentiation of oligodendrocyte precursor cells. Ann Neurol. 2009;65:304-15. https://doi.org/10.1002/ana.21581.

156. Mi S, Blake Pepinsky R, Cadavid D. Blocking LINGO-1 as a therapy to promote CNS repair: from concept to the clinic. CNS Drugs. 2013;27:493-503. https://doi.org/10.1007/s4026 3-013-0068-8.

157. Ruggieri S, Tortorella C, Gasperini C. Anti lingo 1 (opicinumab) a new monoclonal antibody tested in relapsing remitting multiple sclerosis. Expert Rev Neurother. 2017;17:1081-9. https://doi. org/10.1080/14737175.2017.1378098.

158. Cadavid D, Balcer L, Galetta S, Aktas O, Ziemssen T, Vanopdenbosch L, et al. Safety and efficacy of opicinumab in acute optic neuritis (RENEW): a randomised, placebo-controlled, phase 2 trial. Lancet Neurol. 2017;16:189-99. https://doi.org/10.1016/ S1474-4422(16)30377-5.

159. Mellion M, Edwards KR, Hupperts R, Drulović J, Montalban X, Hartung H-P, et al. Efficacy results from the phase 2b SYNERGY study: treatment of disabling multiple sclerosis with the antiLINGO-1 monoclonal antibody opicinumab (S33.004). Neurology. 2017;88(16 Supplement).

160. Peyro Saint Paul L, Debruyne D, Bernard D, Mock DM, Defer GL. Pharmacokinetics and pharmacodynamics of MD1003 (high-dose biotin) in the treatment of progressive multiple sclerosis. Expert Opin Drug Metab Toxicol. 2016;12(3):327-44. https ://doi.org/10.1517/17425255.2016.1136288.

161. Sedel F, Papeix C, Bellanger A, Touitou V, Lebrun-Frenay C, Galanaud D, et al. High doses of biotin in chronic progressive multiple sclerosis: a pilot study. Mult Scler Relat Disord. 2015;4:159-69. https://doi.org/10.1016/j.msard.2015.01.005.

162. Tourbah A, Lebrun-Frenay C, Edan G, Clanet M, Papeix C, Vukusic S, et al. MD1003 (high-dose biotin) for the treatment of progressive multiple sclerosis: a randomised, double-blind, placebo-controlled study. Mult Scler. 2016;22(13):1719-31. https://doi.org/10.1177/1352458516667568.

163. Arnold D. ECTRIMS online library. 26 Oct 2017; 202483. MD1003 in progressive multiple sclerosis: 24-month brain MRI results of the MS-SPI trial. https://onlinelibrary.ectrims-congr ess.eu/ectrims/2017/ACTRIMS-ECTRIMS2017/202483/dougl as.1.arnold.md1003.in.progressive.multiple.sclerosis.24-month .brain.mri.html?f=media=1. Accessed 1 Mar 2018.

164. Sedel F, Bernard D, Mock DM, Tourbah A. Targeting demyelination and virtual hypoxia with high-dose biotin as a treatment for progressive multiple sclerosis. Neuropharmacology. 2016;110:644-53. https://doi.org/10.1016/j.neuropharm .2015.08.028

165. Green AJ, Gelfand JM, Cree BA, Bevan C, Boscardin WJ, Mei $\mathrm{F}$, et al. Clemastine fumarate as a remyelinating therapy for multiple sclerosis (ReBUILD): a randomised, controlled, doubleblind, crossover trial. Lancet. 2017;390:2481-9. https://doi. org/10.1016/S0140-6736(17)32346-2.

166. University of California, San Francisco. Assessment of clemastine fumarate as a remyelinating agent in acute optic neuritis (ReCOVER). ClinicalTrials.gov identifier: NCT02521311. https ://www.ClinicaltrialsGov/Ct2/Show/NCT02521311. Accessed 2 Mar 2018.

167. Uccelli A, Laroni A, Freedman MS. Mesenchymal stem cells for the treatment of multiple sclerosis and other neurological diseases. Lancet Neurol. 2011;10:649-56. https://doi.org/10.1016/ S1474-4422(11)70121-1.

168. Scolding NJ, Pasquini M, Reingold SC, Cohen JA. International conference on cell-based therapies for multiple sclerosis. Cell-based therapeutic strategies for multiple sclerosis. Brain. 2017;140:2776-96. https://doi.org/10.1093/brain/awx154.

169. Karussis D, Karageorgiou C, Vaknin-Dembinsky A, GowdaKurkalli B, Gomori JM, Kassis I, et al. Safety and immunological effects of mesenchymal stem cell transplantation in patients with multiple sclerosis and amyotrophic lateral sclerosis. Arch Neurol. 2010;67:1187-94. https://doi.org/10.1001/archneurol .2010 .248

170. Yamout B, Hourani R, Salti H, Barada W, El-Hajj T, Al-Kutoubi A, et al. Bone marrow mesenchymal stem cell transplantation in patients with multiple sclerosis: a pilot study. J Neuroimmunol. 2010;227:185-9. https://doi.org/10.1016/j.jneur oim.2010.07.013.

171. Rice CM, Mallam EA, Whone AL, Walsh P, Brooks DJ, Kane N, et al. Safety and feasibility of autologous bone marrow cellular therapy in relapsing-progressive multiple sclerosis. Clin Pharmacol Ther. 2010;87:679-85. https://doi.org/10.1038/clpt.2010.44.

172. Mohyeddin Bonab M, Ali Sahraian M, Aghsaie A, Ahmadi Karvigh S, Massoud Hosseinian S, Nikbin B, et al. Autologous mesenchymal stem cell therapy in progressive multiple sclerosis: an open label study. Curr Stem Cell Res Ther. 2012;7:407-14. https://doi.org/10.2174/157488812804484648.

173. Connick P, Kolappan M, Crawley C, Webber DJ, Patani R, Michell AW, et al. Autologous mesenchymal stem cells for the treatment of secondary progressive multiple sclerosis: an open-label phase 2a proof-of-concept study. Lancet Neurol. 2012;11:150-6. https://doi.org/10.1016/S1474-4422(11)70305 -2 .

174. Llufriu S, Sepúlveda M, Blanco Y, Marín P, Moreno B, Berenguer J, et al. Randomized placebo-controlled phase II trial of autologous mesenchymal stem cells in multiple sclerosis. PLoS One. 2014;9:e113936. https://doi.org/10.1371/journ al.pone. 0113936 .

175. Harris VK, Stark J, Vyshkina T, Blackshear L, Joo G, Stefanova $\mathrm{V}$, et al. Phase I trial of intrathecal mesenchymal stem cellderived neural progenitors in progressive multiple sclerosis. EBioMedicine. 2018;29:23-30. https://doi.org/10.1016/j.ebiom 2018.02.002.

176. Arnason BG, Berkovich R, Catania A, Lisak RP, Zaidi M. Mechanisms of action of adrenocorticotropic hormone and other melanocortins relevant to the clinical management of patients with multiple sclerosis. Mult Scler. 2013;19:130-6. https://doi. org/10.1177/1352458512458844.

177. Sponsor: University of Calgary. Collaborator: Alberta Innovates Health Solutions. Domperidone in secondary progressive multiple sclerosis (SPMS). ClinicalTrials.gov identifier: NCT02308137. https://www.clinicaltrials.gov/ct2/show/NCT02 308137. Accessed 2 Mar 2018.

178. Zhornitsky S, Wee Yong V, Koch MW, Mackie A, Potvin S, Patten SB, et al. Quetiapine fumarate for the treatment of multiple sclerosis: focus on myelin repair. CNS Neurosci Ther. 2013;19(10):737-44. https://doi.org/10.1111/cns.12154.

179. Zendedel A, Kashani IR, Azimzadeh M, Pasbakhsh P, Omidi N, Golestani A, et al. Regulatory effect of triiodothyronine on brain myelination and astrogliosis after cuprizone-induced demyelination in mice. Metab Brain Dis. 2016;31:425-33. https://doi. org/10.1007/s11011-015-9781-y.

180. Lycke J. Trials of antivirals in the treatment of multiple sclerosis. Acta Neurol Scand. 2017;136:45-8. https://doi.org/10.1111/ ane.12839.

181. Curtin F, Perron H, Kromminga A, Porchet H, Lang AB. Preclinical and early clinical development of GNbAC1, a humanized IgG4 monoclonal antibody targeting endogenous retroviral MSRV-Env protein. MAbs. 2015;7:265-75. https://doi. org/10.4161/19420862.2014.985021.

182. Hartung H. ECTRIMS online library. 28 Oct 2017; 202643. Week 24 results from a phase IIb trial of GNbAC1 in patients with relapsing remitting multiple sclerosis (CHANGE-MS; Clinical trial assessing the HERV-W Env antagonist GNbAC1 for Efficacy in MS). https://onlinelibrary.ectrims-congress.eu/ ectrims/2017/ACTRIMS-ECTRIMS2017/202643/hans-peter 
.hartung.week.24.results.from.a.phase.iib.trial.of.gnbac1.in. html. Accessed 28 Feb 2018.

183. Apitope. Apitope announces positive ATX-MS-1467 phase IIa data in relapsing multiple sclerosis. https://apitope.com/apito pe-announces-positive-atx-ms-1467-phase-iia-data-relapsingmultiple-sclerosis/. Accessed 2 Mar 2018.

184. Streeter HB, Rigden R, Martin KF, Scolding NJ, Wraith DC. Preclinical development and first-in-human study of ATXMS-1467 for immunotherapy of MS. Neurol Neuroimmunol Neuroinflamm. 2015;2:e93. https://doi.org/10.1212/NXI.00000 00000000093.

185. Chataway J, Martin K, Barrell K, Sharrack B, Stolt P, Wraith DC, et al. Effects of ATX-MS-1467 immunotherapy over 16 weeks in relapsing multiple sclerosis. Neurology. 2018;90(11):e955-62. https://doi.org/10.1212/WNL.00000 00000005118 .

186. Howell MD, Winters ST, Olee T, Powell HC, Carlo DJ, Brostoff SW. Vaccination against experimental allergic encephalomyelitis with T cell receptor peptides. Science. 1989;246:668-70.

187. Bourdette D, Edmonds E, Smith C, Bowen J, Guttmann C, Nagy Z, et al. A highly immunogenic trivalent $\mathrm{T}$ cell receptor peptide vaccine for multiple sclerosis. Mult Scler. 2005;11(5):552-61. https://doi.org/10.1191/1352458505ms122 5 oa.

188. Vandenbark AA, Hashim G, Offner H. Immunization with a synthetic T-cell receptor V-region peptide protects against experimental autoimmune encephalomyelitis. Nature. 1989;341:541-4. https://doi.org/10.1038/341541a0.

189. Gold DP, Smith RA, Golding AB, Morgan EE, Dafashy T, Nelson J, et al. Results of a phase I clinical trial of a T-cell receptor vaccine in patients with multiple sclerosis. II. Comparative analysis of TCR utilization in CSF T-cell populations before and after vaccination with a TCRVb 6 CDR2 peptide. J Neuroimmunol. 1997;76:29-38.

190. Fox E, Wynn D, Cohan S, Rill D, McGuire D, Markowitz C. A randomized clinical trial of autologous T-cell therapy in multiple sclerosis: subset analysis and implications for trial design. Mult Scler. 2012;18:843-52. https://doi.org/10.1177/1352458511 428462.

191. Chataway J, Nicholas R, Todd S, Miller DH, Parsons N, Valdés-Márquez E, et al. A novel adaptive design strategy increases the efficiency of clinical trials in secondary progressive multiple sclerosis. Mult Scler. 2011;17:81-8. https://doi. org/10.1177/1352458510382129.

192. Bauer P, Kieser M. Combining different phases in the development of medical treatments within a single trial. Stat Med. 1999;18:1833-48.

193. Likosky WH, Fireman B, Elmore R, Eno G, Gale K, Goode GB, et al. Intense immunosuppression in chronic progressive multiple sclerosis: the Kaiser study. J Neurol Neurosurg Psychiatry. 1991;54:1055-60.

194. Vandemeulebroecke M, Coffey CS, Thomann MA, Muller KE, Barsdorf A, Arbing R, et al. Group sequential and adaptive designs: a review of basic concepts and points of discussion. Biom J. 2008;50:541-57. https://doi.org/10.1002/bimj.20071 0436.

195. Yang H-T, Ju J-H, Wong Y-T, Shmulevich I, Chiang J-H. Literature-based discovery of new candidates for drug repurposing. Brief Bioinform. 2017;18(3):488-97. https://doi.org/10.1093/ bib/bbw030.

196. Ashburn TT, Thor KB. Drug repositioning: identifying and developing new uses for existing drugs. Nat Rev Drug Discov. 2004;3:673-83. https://doi.org/10.1038/nrd1468.

197. Keiser MJ, Setola V, Irwin JJ, Laggner C, Abbas AI, Hufeisen SJ, et al. Predicting new molecular targets for known drugs. Nature. 2009;462:175-81. https://doi.org/10.1038/nature08506.
198. Campillos M, Kuhn M, Gavin A-C, Jensen LJ, Bork P. Drug target identification using side-effect similarity. Science. 2008;321:263-6. https://doi.org/10.1126/science.1158140.

199. Oprea TI, Mestres J. Drug repurposing: far beyond new targets for old drugs. AAPS J. 2012;14:759-63. https://doi.org/10.1208/ s12248-012-9390-1.

200. Cuatrecasas P. Drug discovery in jeopardy. J Clin Invest. 2006;116:2837-42. https://doi.org/10.1172/JCI29999.

201. Wang Y-Y, Nacher JC, Zhao X-M. Predicting drug targets based on protein domains. Mol Biosyst. 2012;8:1528-34. https://doi. org/10.1039/c2mb05450g.

202. Fliri AF, Loging WT, Thadeio PF, Volkmann RA. Biological spectra analysis: linking biological activity profiles to molecular structure. Proc Natl Acad Sci USA. 2005;102:261-6. https://doi. org/10.1073/pnas.0407790101.

203. Schuffenhauer A, Floersheim P, Acklin P, Jacoby E. Similarity metrics for ligands reflecting the similarity of the target proteins. J Chem Inf Comput Sci. 2003;43(2):391-405. https://doi. org/10.1021/ci025569t.

204. Bajorath J. Computational analysis of ligand relationships within target families. Curr Opin Chem Biol. 2008;12:352-8. https:// doi.org/10.1016/j.cbpa.2008.01.044.

205. Hopkins AL, Groom CR. The druggable genome. Nat Rev Drug Discov. 2002;1:727-30. https://doi.org/10.1038/nrd892.

206. Faissner S, Mishra M, Kaushik DK, Wang J, Fan Y, Silva C, et al. Systematic screening of generic drugs for progressive multiple sclerosis identifies clomipramine as a promising therapeutic. Nat Commun. 2017;8:1990. https://doi.org/10.1038/s41467-01702119-6.

207. Vesterinen HM, Connick P, Irvine CMJ, Sena ES, Egan KJ, Carmichael GG, et al. Drug repurposing: a systematic approach to evaluate candidate oral neuroprotective interventions for secondary progressive multiple sclerosis. PLoS One. 2015;10:e0117705. https://doi.org/10.1371/journal.pone.01177 05.

208. Fox RJ, Coffey CS, Cudkowicz ME, Gleason T, Goodman A, Klawiter EC, et al. Design, rationale, and baseline characteristics of the randomized double-blind phase II clinical trial of ibudilast in progressive multiple sclerosis. Contemp Clin Trials. 2016;50:166-77. https://doi.org/10.1016/j.cct.2016.08.009.

209. Conway D, Cohen JA. Combination therapy in multiple sclerosis. Lancet Neurol. 2010;9:299-308. https://doi.org/10.1016/S1474 -4422(10)70007-7.

210. Milo R, Panitch H. Combination therapy in multiple sclerosis. J Neuroimmunol. 2011;231:23-31. https://doi.org/10.1016/J. JNEUROIM.2010.10.021.

211. Lublin FD, Cofield SS, Cutter GR, Conwit R, Narayana PA, Nelson F, et al. Randomized study combining interferon and glatiramer acetate in multiple sclerosis. Ann Neurol. 2013;73:327-40. https://doi.org/10.1002/ana.23863.

212. Cohen JA, Imrey PB, Calabresi PA, Edwards KR, Eickenhorst T, Felton WL, et al. Results of the Avonex Combination Trial (ACT) in relapsing-remitting MS. Neurology. 2009;72:535-41. https://doi.org/10.1212/01.wnl.0000341934.12142.74.

213. Rudick RA, Stuart WH, Calabresi PA, Confavreux C, Galetta SL, Radue E-W, et al. Natalizumab plus interferon beta-1a for relapsing multiple sclerosis. N Engl J Med. 2006;354:911-23. https://doi.org/10.1056/NEJMoa044396.

214. Goodman AD, Rossman H, Bar-Or A, Miller A, Miller DH, Schmierer K, et al. GLANCE: results of a phase 2, randomized, double-blind, placebo-controlled study. Neurology. 2009;72:80612. https://doi.org/10.1212/01.wnl.0000343880.13764.69.

215. Montalban X, Gold R, Thompson AJ, Otero-Romero S, Amato MP, Chandraratna D, et al. ECTRIMS/EAN guideline on the pharmacological treatment of people with multiple sclerosis. Eur J Neurol. 2018;25:215-37. https://doi.org/10.1111/ene.13536. 
216. Filippini G. Ocrelizumab appears to reduce relapse and disability in multiple sclerosis but quality of evidence is moderate. Evid Based Med. 2017;22:215-6. https://doi.org/10.1136/ebmed -2017-110721.

217. Chataway J. Tackling progression in multiple sclerosis. Lancet Neurol. 2018;17(6):489-91. https://doi.org/10.1016/S1474 -4422(18)30158-3.

218. Steinman L. Multiple sclerosis: a two-stage disease. Nat Immunol. 2001;2:762-4. https://doi.org/10.1038/ni0901-762.

219. Cambron M, Mostert J, Haentjens P, D'Hooghe M, Nagels G, Willekens B, et al. Fluoxetine in progressive multiple sclerosis (FLUOX-PMS): study protocol for a randomized controlled trial. Trials. 2014;15:37. https://doi.org/10.1186/1745-6215-15-37.

220. Kosa P, Ghazali D, Tanigawa M, Barbour C, Cortese I, Kelley $\mathrm{W}$, et al. Development of a sensitive outcome for economical drug screening for progressive multiple sclerosis treatment. Front Neurol. 2016;7:131. https://doi.org/10.3389/fneur.2016.00131.

221. Spain RI, Powers K, Murchison C, Heriza E, Horak FB, Simon JBD. Lipoic acid for neuroprotection in secondary progressive multiple. ECTRIMS online library. 16 Sep 2016; 147064.

222. Ratzer R, Iversen P, Börnsen L, Dyrby TB, Romme Christensen J, Ammitzbøll C, et al. Monthly oral methylprednisolone pulse treatment in progressive multiple sclerosis. Mult Scler. 2016;22:926-34. https://doi.org/10.1177/1352458515605908.

223. Innate Immunotherapeutics. Press release: top-line results for trial of MIS416 in patients with secondary progressive multiple sclerosis. 2017. http://www.innateimmuno.com/irm/ PDF/1424_0/TopLineResultsforTrialofMIS416. Accessed 2 Apr 2018.

224. Montalban X, Hemmer B, Rammohan K, Giovannoni G, de Seze J, Bar-Or A, Arnold DL, Sauter A, Kakarieka A, Masterman D,
Chin P, Garren H, Wolinsky J, On behalf of the OCI. Efficacy and safety of ocrelizumab in primary progressive multiple sclerosis: results of the placebo-controlled, double-blind, phase III ORATORIO study (abstract no. 228). Mult Scler. 2015;21:781-2.

225. Komori M, Lin YC, Cortese I, Blake A, Ohayon J, Cherup J, et al. Insufficient disease inhibition by intrathecal rituximab in progressive multiple sclerosis. Ann Clin Transl Neurol. 2016;3:16679. https://doi.org/10.1002/acn3.293.

226. Kappos L, Bar-Or A, Cree B, Fox R, Giovannoni G, Gold R, Vermersch P, Arnould S, Sidorenko T, Wolf C, Wallstroem E DF. Efficacy and safety of siponimod in secondary progressive multiple sclerosis: results of the placebo controlled, double-blind, phase III EXPAND study. ECTRIMS online library. 2016.

227. Opexa Therapeutics. Press release: phase $2 \mathrm{~b}$ Abili-T trial of Tcelna ${ }^{\circledR}$ (imilecleucel-T) in secondary progressive multiple sclerosis did not meet primary endpoint. 28 Oct 2016. http:// www.opexatherapeutics.com/files/default_nt5r45v4toey75ea2gj6 wb.html. Accessed 5 May 2017.

228. Cadavid D, Edwards KR, Hupperts R, Drulović J, Montalban X, Hartung H.-P, Brochet B, Calabresi PA, Rudick R, Ibrahim A, Zhang Y, Xu L; On behalf of the S investigators. Efficacy analysis of opicinumab in relapsing multiple sclerosis. ECTRIMS online library. 16 Sep 2016; 147038. http://onlinelibrary.ectri ms-congress.eu/ectrims/2016/32nd/147038/diego.cadavid.effic acy.analysis.of.opicinumab.in.relapsing.multiple.sclerosis. $\mathrm{html}$ ? $\mathrm{f}=\mathrm{m} 1$. Accessed 19 Apr 2017.

229. Rice CM, Marks DI, Ben-Shlomo Y, Evangelou N, Morgan PS, Metcalfe C, et al. Assessment of bone marrow-derived Cellular Therapy in progressive Multiple Sclerosis (ACTiMuS): study protocol for a randomised controlled trial. Trials. 2015;16:463. https://doi.org/10.1186/s13063-015-0953-1. 